\title{
CHOICE IN THE TRANSITION: \\ SCHOOL DESEGREGATION \\ AND THE CORRECTIVE IDEAL
}

\author{
Paul Gewirtz* \\ TABLE of Contents
}

Introduction .................................. 729

I. The Corrective Conception of Antidiscrimination Law ..... 731

A. Three Approaches to Racial Justice ............. 731

B. The Structure of the Corrective Conception ........ 731

II. The Corrective Conception, School Desegregation, and

Freedom of Choice......................... 735

A. The Distributive Explanation $\ldots \ldots \ldots \ldots \ldots \ldots \ldots \ldots \ldots \ldots \ldots$

B. The Prohibitory Explanation ................. 738

C. The Corrective Explanation ................. 739

1. The Concept of Tainted Choice............. 741

a. Restricted Options .................... 743

b. Duress ................................ 744

c. Distorted Attitudes .................... 745

d. Information and Coordination Problems ....... 748

2. The Remedial Insufficiency of Liberty and the

Duty to Integrate ...................... 749

III. Freedom of Choice Today ...................... 755

A. Choice in Order to Avoid Paternalism ............ 756

B. Choice Without Taint ...................... 760

C. Choice as a Means to an Integrated End.......... 761

D. Choice as the Best Means to Achieve Multiple

Corrective Goals ............................ 772

E. Choice as an Interdistrict Remedy ............. 778

IV. Boundaries of the Corrective Conception ............. 782

A. Context: General Empirical Problems .......... 783

B. Time: The Problem of Termination ............. 789

Conclusion .................................. 798

* Professor of Law, Yale Law School. For giving their time and intelligence to help make this a better piece of work, I am grateful to Zoë Baird, Craig Becker, Paul Brest, Owen Fiss, Joseph Goldstein, Catherine Iino, Paul Kahn, Pamela Karlan, Randall Kennedy, Anthony Kronman, Burke Marshall, George Priest, Peter Schuck, Cass Sunstein, Richard Taranto, Judith Thomson, Barbara Underwood, and my superb research assistants, Paul Holtzman and Randolph Moss. 


\section{INTRODUCTION}

This is an essay about the corrective aspiration of the law of racial discrimination-the commitment, expressed again and again in the case law, to eliminate the effects of past discrimination. This aspiration is most obviously reflected in remedies that courts order once specific violations of the Constitution or antidiscrimination statutes are shown. In broader form, it is also reflected in measures such as affirmative action that other institutions undertake to overcome more pervasive discrimination. Understanding what this corrective aspiration really means, and struggling with the transitional conflicts of moving from an unjust situation to a more just one, have been the distinctive civil rights challenges for this generation of lawyers and judges.

In antidiscrimination law, the basic concept of the wrong to be corrected is defined by the "antidiscrimination principle" 1 as the raciallybased disadvantaging of blacks. ${ }^{2}$ The harms that are wrongful are those resulting from so-called "purposeful discrimination"- that is, racially prejudiced goals or attitudes-not discrimination defined in some other posssible way. While some have questioned whether it is appropriate to focus especially on harms caused by purposeful discrimination, and would focus instead on black "disadvantage" without linking it to purposeful discrimination, ${ }^{3}$ this notion of the harm to be eliminated corresponds, I think, to what most people believe are the distinctively terrible wrongs that blacks have suffered: not simply that they have wound up in an inferior position, but that they were deliberately subordinated and remain so today largely because of the effects of purposeful discrimination extending throughout American society over many years. The distinctive moral force of the corrective approach is that it builds upon the strong moral claim that purposeful discrimination is a wrong whose effects should be eradicated.

This essay celebrates the extraordinary power of corrective ideas if they are applied vigorously, but also explores some of the difficulties borne of these ambitions. I focus here on the corrective aspiration in its most basic setting, judicial remedies for proven violations of the equal protection clause, and in a single area of antidiscrimination law, remedies for unlawful school segregation. It is in this area that corrective ideas probably have received their fullest elaboration. In particu-

1. See, e.g., Brest, The Supreme Court, 1975 Term-Foreword: In Defense of the Antidiscrimination Principle, 90 Harv. L. Rev. 1 (1976).

2. This essay focuses on corrective principles as applied to the paradigmatic problem of antidiscrimination law: racial discrimination against blacks. The antidiscrimination principle can be and has been extended more broadly-to other racial groups and to such traits as sex, ethnic origin, and alienage-and corrective principles play an important role in these branches of antidiscrimination law as well. While my analysis has obvious relevance to these other areas, they are beyond the scope of my discussion here.

3. See, e.g., Fiss, Groups and the Equal Protection Clause, 5 Phil. \& Pub. Aff. 107, $147-70$ (1976). 
lar, I address an issue whose intellectual interest is equalled by its current practical importance: the appropriateness of the central feature of the school desegregation policy of President Reagan's Administration. Reflecting views that have won increasing support from some well-known commentators and some lower federal courts, ${ }^{4}$ the Administration has argued that once unlawful school segregation has been shown, courts should simply give families in the school system "freedom to choose" which school their children will attend, rather than order the customary remedial step of mandatory pupil reassignments to produce integration. I argue that the corrective conception requires rejection of the Administration's position. The Administration's choice approach will perpetuate, not eliminate, the effects of discrimination.

But this challenge to the Administration's position must overcome at least two major problems. First, giving effect to individual choices is a very strong value in our culture. In the name of providing blacks a remedy, rejecting choice may override some blacks' choices. Should corrective ideas be extended this far? Second, the contemporary school desegregation effort has often revealed extraordinary practical obstacles to the full implementation of corrective ideas. In light of those obstacles-particularly the current problems with traditional mandatory integration remedies in some situations-is the choice approach proposed by the current Administration at least worth trying? Even if not, what about other types of choice remedies?

While the issue of choice has great contemporary importance in its own right, it is also an excellent vehicle for exploring the corrective approach more generally, and thus for illuminating some general characteristics of current antidiscrimination doctrine. This is my larger concern here. Most significantly, analysis of freedom of choice illustrates the difference between corrective rules and "end-state" rules, and the tensions between the two. In the "end-state"- that is, once discrimination and its effects have been eliminated-nothing in the equal protection clause prevents the government from adopting policies that give effect to individual choices. A commitment to the corrective conception, however, means that freedom of choice may be impermissible during the period necessary to remedy unlawful discrimination; corrective norms may require interference with choice even though end-state

4. See, e.g., R. Wolters, The Burden of Brown: Thirty Years of School Desegregation 275-80, 287-88 (1984); D. Bell, Race, Racism and American Law 410-11 (2d ed. 1980); N. Glazer, Affirmative Discrimination: Ethnic Inequality and Public Policy 108-09, 118, 123, 128-29 (1975); N. St. John, School Desegregation: Outcomes for Children 132-36 (1975); Coleman, New Incentives for Desegregation, Hum. Rts., Fall 1978, at 10; Goodman, The Desegregation Dilemma: A Vote for Voluntarism, 1979 Wash. U.L.Q. 407; Ravitch, Desegregation: Varieties of Meaning, in Shades of Brown: New Perspectives on School Desegregation 44-45 (D. Bell ed. 1980). The Reagan Administration's enforcement policies and recent lower court decisions approving choice remedies in Chicago, Buffalo, and elsewhere are discussed infra notes 85-180 and accompanying text. 
norms would respect it. Explaining why this should be so illustrates the power of the corrective idea, but also points to a recurring, inherent problem: since transitional remedial rules may be different from endstate rules, the corrective enterprise requires policing the boundary between the two.

\section{The Corrective Conception of Antidiscrimination LaW}

\section{A. Three Approaches to Racial Justice}

To understand the choice issue, one must first distinguish between the corrective conception and two other approaches to racial justice, which I will call the prohibitory conception and the distributive conception. The prohibitory approach is narrow; like the corrective approach, it accepts the antidiscrimination principle as the definition of wrongful conduct, but it views the goal of antidiscrimination law as simply stopping new violations of the principle. It is completely future-oriented. The corrective conception, by contrast, requires significant measures to eliminate the ongoing effects of discrimination; it requires remedial intervention that goes beyond the prohibitions of the antidiscrimination principle itself, since merely assuring prospective adherence to that principle will not undo continuing effects of past violations.

The distributive conception rejects both the centrality of the antidiscrimination principle and the backward looking, remedial focus of the corrective view. Instead, racial justice under the Constitution is understood as a specific racial distribution-for example, a representation of the races in various institutions in proportion to their representation in the population. Other distributions are prohibited, whether or not they are caused by "wrongful" actions such as violations of the antidiscrimination principle. The corrective conception is not distributive in this sense since it does not mandate a specific distribution of the races as the ultimate constitutional design; rather, it prohibits race-based disadvantaging and requires corrective efforts to eliminate the effects of past discrimination. This might ultimately lead to an arrangement favored by some distributive theory, but it might not. Under corrective theory, the ultimate distribution depends upon the uncertain empirical consequences of both eliminating discrimination and its effects and implementing whatever other social policies among the many constitutionally permissible ones are adopted in the end-state; the distribution is not determined by some a priori conception of the appropriate allocation.

\section{B. The Structure of the Corrective Conception}

A corrective approach can be either broad or narrow. In its broader form, corrective steps are directed toward the continuing effects of our country's long history of racial discrimination. In its narrow form, the law furnishes remedies for identified acts of 
discrimination. A corrective argument in equal protection cases, my primary subject here, takes the narrower form. Although the structure of the argument has not been made sufficiently explicit, it consists of a concept of the violation, a concept of linkage between remedial action and the violation, and principles of permissible limits on the remedy.

The violation consists of acts and effects. Under the prevailing interpretation of the Constitution, a defendant "violates" the equal protection clause only if (1) its own actions, not those of unnamed or unnamable parties, are (2) racially-based or intentionally discriminatory acts, not simply acts that have an adverse racial effect. ${ }^{5}$ Even though the antidiscrimination principle condemns harms resulting from purposeful discrimination, courts committed to that principle could easily have defined the equal protection violation more broadly to include acts by a defendant that are not themselves intentionally discriminatory, but that perpetuate or exacerbate the effects of intentional discrimination by others, including the cumulative effects of pervasive intentional discrimination throughout American history. Such a liability rule, qualified perhaps by allowing the defendant to demonstrate strong overriding justifications, would have furthered the broadly corrective goal of eliminating effects of past violations of the antidiscrimination principle. ${ }^{6}$ It is now clear, however, that the defendant itself must be shown to have intentionally discriminated to establish a violation of the equal protection clause.

The second element of the structure of corrective arguments is a concept of linkage between the remedy and the violation. The defendant's violation is not simply a trigger for judicially-mandated action, unleashing a freewheeling judicial policy-making power. Rather, the remedy must be linked to the violation as a corrective, a measure that seeks to eliminate the violation's harmful effects. For example, if the violation is the defendant's intentional refusal to hire black teachers in its schools, the appropriate remedy would not only insist that this practice cease, but would also include corrective steps such as paying damages to the excluded teachers and eliminating lingering consequences that the violation has had on the composition of the teaching staff.

The linkage principle is captured in the Supreme Court's frequent assertion that "the scope of the remedy is determined by the nature and extent of the constitutional violation."7 This linkage concept is

5. See, e.g., Columbus Bd. of Educ. v. Penick, 443 U.S. 449, 464 (1979); Washington v. Davis, 426 U.S. 229, 240 (1976).

6. The Supreme Court, in fact, interpreted title VII of the Civil Rights Act of 1964, 42 U.S.C. $\$ 2000$ e (1982), to embody such a liability rule, Griggs v. Duke Power Co., 401 U.S. 424, 429-32 (1971), even though the Act was no more specific in this regard than the Constitution.

7. Milliken v. Bradley (Milliken I), 418 U.S. 717, 744 (1974); see General Bldg. Contractors Ass'n v. Pennsylvania, 458 U.S. 375, 399 (1982); Dayton Bd. of Educ. v. Brinkman (Dayton I), 433 U.S. 406, 420 (1977); Milliken v. Bradley (Milliken II), 433 U.S. 267, 280 (1977). 
both a principle of empowerment and a principle of constraint. In its empowering role, it counsels courts to use the "breadth and flexibility ... inherent in equitable remedies" to remove "all vestiges"8 of the violation "root and branch"9 and "to restore the victims of discriminatory conduct to the position they would have occupied in the absence of such conduct."10 In its constraining role, the linkage concept counsels courts to go no further than to eliminate effects of violations. "[F]ederal-court decrees exceed appropriate limits if they are aimed at eliminating a condition that does not violate the Constitution or does not flow from such a violation." 11 Courts, in other words, are not free to provide "remedies" for conditions that are not caused by a violation of law. Because the Supreme Court has defined the equal protection violation as the defendant's own intentional discrimination, the concepts of violation and linkage, taken together, do not allow courts to "reach" conditions of black disadvantage or separation not causally linked to the defendant's intentional discrimination; they do not authorize judicial remedies for conditions that reflect pervasive, historic racial discrimination, or for conditions caused by factors unrelated to discrimination. The Constitution, in other words, does not provide a remedy for all harms causally linked to purposeful discrimination. While equal protection doctrine implements the antidiscrimination principle in a corrective way, it is a narrowly corrective approach.

Nevertheless, the basic definitions of violation and linkage confine remedies much less tightly than is generally believed. While the Court's linkage principle has been called "an impoverished notion of remedy," 12 it is actually a powerful engine of transformation. Since the defendant's violation often is extensive, and includes a broad range of harmful effects, the linkage principle requires a commensurately broad remedy. This is particularly so in the quite common event that the defendant's violations have occurred over a long period of time. ${ }^{13}$ (One important but unnoticed curiosity of school desegregation cases is that

8. Swann v. Charlotte-Mecklenburg Bd. of Educ., 402 U.S. 1, 15 (1971).

9. Green v. County School Bd., 391 U.S. 430, 438 (1968); see id. at 437-38 \& n.4; Columbus Bd. of Educ. v. Penick, 443 U.S. 449, 458-61 (1979); Keyes v. School Dist. No. 1, 413 U.S. 189, 200 (1973); Wright v. Council of Emporia, 407 U.S. 451, 460, 463 (1972).

10. Milliken v. Bradley (Milliken I), 418 U.S. 717, 746 (1974).

11. Milliken v. Bradley (Milliken II), 433 U.S. 267, 282 (1977).

12. Fiss, The Supreme Court, 1978 Term-Foreword: The Forms of Justice, 93 Harv. L. Rev. 1, 47 (1979).

13. Longstanding discrimination is likely to have both direct and indirect effects on individuals, institutions, and the community as a whole. There may, in turn, be feedback effects on those directly affected, as well as effects on subsequent generations. See Schnapper, Perpetuation of Past Discrimination, 96 Harv. L. Rev. 828, 834-36, 839, $856-58$ (1983). Of course, the scope of findings of violation (and therefore the scope of a permissible remedy) will depend on the facts of particular cases and the legal standards governing proof of those facts-for example, the selection of a concept of causation-in-fact, the allocation of burdens of proof, and presumptions. See infra note 182 
the Supreme Court has not invoked statutes of limitation to confine the temporal reach of the defendant's liability. ${ }^{14}$ ) Where broad effects are found, a broad remedy seeking to achieve a range of remedial goals is justified.

A third element in the structure of corrective arguments-principles of limitation that go beyond the basic constraints of the linkage principle-is perhaps not surprising given the potency of the basic corrective principle. The courts have been altogether confusing, however, about whether and to what extent equitable remedies may do less than eliminate all actual effects of the violation. ${ }^{15}$ One possibility, of course, is to build limiting notions into the structure of remedial arguments by narrowly defining the violation to include only certain categories of effects deemed legally relevant or "proximately caused" by illegalities. This conceptual maneuver would preserve the general corrective objective of eliminating "all vestiges" of the violation, but would limit particular corrective goals by restricting the category of "vestiges" that come within the scope of the violation. But this does not seem to be a route of limitation in antidiscrimination cases, at least not explicitly. ${ }^{16}$ Rather, when limiting ideas surface, the courts generally focus directly on the remedy and indicate that certain competing values will override corrective goals. ${ }^{17}$

Even leaving room for principles of limitation, the corrective conception has enormous generative power. As we shall see in more detail below, the corrective idea unleashes a transitional regime during which courts temporarily adopt remedial rules that would be inappropriate if discrimination had not occurred and that will become inappropriate once the effects of discrimination have been eliminated. During this transition period, it is not sufficient simply to prohibit new race-based decisions disadvantaging blacks. Remedial strategies and transformative actions are appropriate to remove the effects of past discrimina-

and accompanying text. But under any reasonable standards of proof, the effects of longstanding discrimination are likely to be extensive.

14. Although the Supreme Court has never explained this curiosity, these cases may come within a traditional exception for "continuing" violations. See, e.g., Milton v. Weinberger, 645 F.2d 1070, 1074-77 (D.C. Cir. 1981).

15. See Gewirtz, Remedies and Resistance, 92 Yale L.J. 585, 589-90 (1983).

16. But compare Swann v. Charlotte-Mecklenburg Bd. of Educ., 402 U.S. 1, 20-21 (1971) (relying on residential housing effects of school segregation as a reason why busing is often necessary as a remedy for school segregation) with id. at 22 ("The elimination of racial discrimination in public schools . . . should not be retarded by efforts to achieve broader purposes lying beyond the jurisdiction of school authorities. One vehicle can carry only a limited amount of baggage.").

17. For a discussion of this form of remedial interest balancing in constitutional cases, see Gewirtz, supra note 15, at 598-608. Interest balancing permits the courts to order a limited remedy-one that does not eliminate all effects of the violation-because a more effective remedy is deemed too costly to competing interests. This principle of limitation is to be distinguished from acknowledging that in certain instances a more effective remedy may simply be impossible to achieve. ld. at 591-98. 
tion. As a result, during the transition courts may prohibit actions that would be permitted in the racial end-state, require actions that would be prohibited or at most permitted in the end-state, and permit actions that would be impermissible in the end-state. Race-conscious affirmative action is simply one particularly controversial example of such transitional steps. If one believes that antidiscrimination law should be merely prohibitory, these measures would be inappropriate for a court to adopt even temporarily. If one views antidiscrimination law as distributive, these measures would be appropriate not simply temporarily but as end-state requirements. But those who hold to a corrective conception of antidiscrimination law must endure the tension between transitional rules and end-state rules. Time becomes a pervasive preoccupation: looking backward, the corrective approach seeks to purge the present of the past; looking forward, it always anticipates the end of its efforts.

\section{The Corrective Conception, School Desegregation, and FREEDOM OF CHOICE}

With these three conceptions in mind, we can now turn to the issue of choice. An appropriate starting point is Green v. County School Board, ${ }^{18}$ the Supreme Court's first major case involving the substantive requirements of a desegregation remedy. Decided in 1968, Green crystalized the corrective perspective in equal protection cases; it is the predicate for any discussion of the contemporary problem of choice. The facts of Green have an apparent simplicity. New Kent County, Virginia, had only two schools, a combined elementary and high school for whites, and a combined elementary and high school for blacks. There was little residential segregation, and until the mid-1960s school segregation was achieved by assigning students to schools according to their race. In response to a desegregation suit, New Kent County (like many other southern school districts ${ }^{19}$ ) adopted a freedom of choice plan allowing all students to choose which school they would attend; both schools were open to blacks. ${ }^{20}$ Under the plan, fifteen percent of blacks

18. 391 U.S. 430 (1968).

19. In 1967, "[m]ost southern school districts in the process of desegregation [were] operating under freedom-of-choice plans." Dunn, Title VI, The Guidelines and School Desegregation in the South, 53 Va. L. Rev. 42, 44 (1967). Indeed, prior to Green, use of freedom of choice under some circumstances had been explicitly endorsed by the United States Department of Health, Education, and Welfare (HEW), which was one of the most significant forces for desegregation in the country. See United States v. Jefferson County Bd. of Educ., 372 F.2d 836 (5th Cir. 1966), aff'd, 380 F.2d 385 (5th Cir.) (en banc), cert. denied, 389 U.S. 840 (1967); S. Wasby, A. D'Amato \& R. Metrailer, Desegregation from Brown to Alexander 376-407 (1977); Dunn, supra, at 44; U.S. Office of Education, HEW, Revised Statement of Policies for School Desegregation Under Title VI of the Civil Rights Act of 1964 (Mar. 1966) [hereinafter cited as HEW Revised Statement].

20. Green, 39I U.S. at 431-32. The opinion describes the freedom of choice plan as 
in the school system chose to attend the formerly all-white school. No white student chose to attend the school formerly designated as the black school. ${ }^{21}$ Thus, eighty-five percent of the blacks in the system were attending an all-black school.

The Supreme Court held that New Kent County's system of assigning students based on their choices was constitutionally impermissible. Far from being a right, freedom of choice was unlawful. The decision was unanimous, but to my mind the result has never been adequately explained or analyzed by the Court or commentators. ${ }^{22}$ Justice Brennan began his opinion for the Court by stating that the question was whether New Kent County had satisfied the requirement of Brown II ${ }^{23}$ that the defendant " 'achieve a system of determining admission to the public schools on a non-racial basis." "24 Why does freedom of choice not achieve this? Giving pupils a choice among schools seems to be neither a system of racial assignment nor a system of "determining admission" on a racial basis; instead, it seems to permit blacks as well as whites to choose the school they want without government interference. Claiming to act on behalf of blacks, the Court disregarded their choices. What explains this result?

\section{A. The Distributive Explanation}

Each of the three conceptions of racial justice described above provides a way of looking at Green and evaluating freedom of choice. An adherent of the distributive conception might explain Green by claiming that integration is the permanent end-state distribution of students required by the Constitution. Under this view, the simple existence of a segregated pattern in New Kent County offended the Constitution, without regard to whether the defendant's intentional segregation had caused the pattern. The choice plan was impermissible simply because it failed to produce integration-and would have been impermissible even if the defendant had not engaged in intentional segregation, since integration is viewed as an independent normative requirement of the equal protection clause. According to Professor Owen Fiss, "Green started to move in that direction. This was implicit in the Court's decision to hold the student assignment plan unconstitutional even though it was willing to assume that the plan was free from racial assignment."25 For Professor Fiss, such a distributive conception is the cor-

allowing a "pupil" to choose, id. at 431 , but in most situations, it was probably the parents who were making the choice on behalf of the child.

21. Id. at 441 .

22. Professor Paul Brest, for example, calls it a "relatively easy case." Brest, supra note 1 , at 35 .

23. 349 U.S. 294 (1955).

24. 391 U.S. at 432 (quoting Brown II, 349 U.S. at 300-01).

25. Fiss, School Desegregation: The Uncertain Path of the Law, 4 Phil. \& Pub. Aff. 3, 19 (1974). 
rect approach; he would have us "abandon the illusory search for the incidents of past discrimination" 26 since his constitutional case for integration does not turn on past discrimination.

This view of the status of integration-and, by implication, the status of choice-rests on a cluster of empirical beliefs and normative judgments concerning certain harms of racial separation. ${ }^{27}$ Among its other problems, however, the view that the Constitution permanently mandates integration without regard to the causes of nonintegration fails to take adequate account of values of ethnic group identity and pluralism that might be furthered in a nonintegrated setting. It disregards the fact that blacks themselves, like most other ethnic groups in the United States, might come to prefer nonintegrated settings, believing that important interests are served by institutions in which they are not an "integrated" racial minority. If integration were deemed to be a permanent end-state requirement, such conditions would not be allowed in institutions subject to the Constitution's requirements. Courts, moreover, would be permanently deciding what degree of racial integration is the preferable mix, permanently ordering other institutions to carry out that mandate, and permanently interfering with people's lives.

Even more importantly, since the distributive theory seeks to condemn racial segregation for reasons other than its causal link to racial discrimination, the moral basis for the theory is broader, more uncertain, and surely more contested than the basis for a corrective theory. By refusing to tie its imperatives to our history of racial oppression, the distributive theory cannot easily be limited to a requirement that the government only secure racial integration; it inevitably requires the government to affirmatively maintain integration of all sorts of other social classes and groups. Such a theory may have some appeal, but it would involve an ongoing judicial reorganization of social relations that is difficult to imagine. Most significantly here, it obliterates a distinction between claims of economic (or class) justice and the narrower idea of racial justice - that is, the claim that the conditions of black Americans are uniquely wrong and deserving of a remedy because of their causal link to longstanding racial oppression. Inevitably, a general distributive theory sacrifices the distinctive moral power of a plea for racial justice, holding it hostage until broader distributive ideas gain acceptance.

Moreover, the courts have explicitly rejected the distributive conception, including the integrationists' position, as constitutional doc-

26. Id. at 39 .

27. See Fiss, Racial Imbalance in the Public Schools: The Constitutional Concepts, 78 Harv. L. Rev. 564, 612-17 (1965); Fiss, supra note 25, at 36-39; Yudof, Nondiscrimination and Beyond: The Search for Principle in Supreme Court Desegregation Decisions, in School Desegregation: Past, Present, and Future 97, 107-09 (W. Stephan \& J. Feagin eds. 1980). 
trine. A particular racial condition is an unconstitutional racial inequality only if it is causally related to the defendant's purposeful racial discrimination. ${ }^{28}$ Thus, a freedom of choice system is not unlawful simply because it produces a racially concentrated distribution, without regard to whether the defendant had previously engaged in intentional segregation. To explain Green by invoking a distributive notion that integration is a permanent constitutional requirement is to invoke a theory without support in current doctrine.

\section{B. The Prohibitory Explanation}

A second way to understand Green is provided by the prohibitory approach, which permits courts to enjoin new violations of the antidiscrimination principle. Under this view, the freedom of choice plan was unacceptable because New Kent County adopted the plan with the same discriminatory purpose that accompanied the previous explicit system of racial assignments. Far from being a remedy for past violations, the freedom of choice plan was yet a new act of purposeful discrimination, simply a disguised form of achieving a desired racial pattern of school assignments.

The Supreme Court refused to justify its rejection of choice in the name of prohibitory principles, however, ${ }^{29}$ and it is not difficult to see why. Although on the record in Green a trier of fact undoubtedly could have concluded that the plan was adopted for the purpose of maintaining racial separation, the trial court in Green had not taken that view. ${ }^{30}$ Moreover, even if the Supreme Court were prepared to substitute its view of the facts for the trial court's, striking down the free choice plan on prohibitory grounds would have required a more complicated argument. Even if the county's purpose in adopting the plan was to maintain racial separation-based on a prediction of how individuals would choose-the Court would still have needed to explain why the intervening choices of most blacks to remain separate did not insulate the defendant from responsibility for the segregated pattern. The school board may have wanted racial separation-but if most blacks wanted racial separation too, why was it impermissible for the government to

28. See Columbus Bd. of Educ. v. Penick, 443 U.S. 449, 464-65 (1979); Dayton Bd. of Educ. v. Brinkman (Dayton I), 433 U.S. 406, 420 (1977); Washington v. Davis, 426 U.S. 229, 240 (1976).

29. See Green, 391 U.S. at $439-40$.

30. See id. at 438-39, 442 n.6 (noting school board's deliberate delay in taking any steps to comply with Brown, and stating that "conditions in this county present a classic case" for geographic zoning, which would have "readily achieved" a unitary system). "Freedom of choice" seems to have been used as a device of evasion and resistance in many other leading cases of the period. See, e.g., Griffin v. County School Bd., 377 U.S. 218 (1964); Poindexter v. Louisiana Fin. Assistance Comm'n, 296 F. Supp. 686 (E.D. La.), aff'd per curiam sub nom. Louisiana Educ. Comm'n for Needy Children v. Poindexter, 393 U.S. 17 (1968); Brown v. South Carolina State Bd. of Educ., 296 F. Supp. 199 (D.S.C.), affd per curiam, 393 U.S. 222 (1968). 
give blacks the choice?31

The more fundamental problem with the prohibitory approach, however, is that it is simply too narrow. Even had the Court in Green been able to offer a rationale for striking down the plan on prohibitory grounds alone, that would have reflected a much too limited approach to the school segregation problem. Under prohibitory principles, only new violations may be challenged, and these often do not exist or are hard to prove. Even where there is an adequate factual predicate for prohibitory relief, the remedy is limited to ordering new violations to cease. This approach provides no incentive for school boards to stop their violations until ordered to do so. Most significantly, it does not address the altogether different problem of uprooting the ongoing effects of past violations. These effects will continue to work their harms even if new violations end. Stopping new violations is necessary but not sufficient. ${ }^{32}$ By 1968, the Supreme Court may have felt the time had come to move beyond the limitations of prohibitory ideas, and to put corrective principles at center stage..$^{33}$

\section{G. The Corrective Explanation}

The Court explained its rejection of freedom of choice in corrective terms. The choice plan was impermissible because it failed to "eliminate the discriminatory effects of the past." 34 In so holding, Green cemented the Court's commitment to a corrective conception of

31. This question is hardly unique to the prohibitory theory-a version of it reappears with respect to the corrective theory that the Court used and that I defend below-but it does undercut the comparative persuasiveness of the prohibitory theory.

32. See Dayton Bd. of Educ. v. Brinkman (Dayton II), 443 U.S. 526, 538 (1979).

33. Ronald Dworkin has invoked a prohibitory theory as a basis for rejecting pupil assignment policies that do not actually produce integration. According to Dworkin, requiring integration is the only way to "negate the antecedent probability" that de jure segregation will continue to govern the pupil assignment process. Dworkin, Social Sciences and Constitutional Rights-The Consequences of Uncertainty, 6 J.L. \& Educ. 3, 12 (1977). Dworkin's argument is curious since courts generally do not insist upon prophylactic measures of this oblique yet intrusive sort, even after finding that a particular defendant has already violated the law. While an unusually specific preventive decree is sometimes justified by a showing that a particular defendant's repeated law violations make the defendant distinctively untrustworthy, see Gewirtz, supra note 15 , at 596-98, Dworkin's theory does not rest on a particularized predicate. His intrusive prophylactic requirement rests on a much more generalized empirical judgment that pupil assignment processes are "likely to be corrupt," Dworkin, supra, at 11 (a theory that is especially surprising since he earlier criticizes the uncertain empirical basis of other theories of integration, see id. at 7-9). Dworkin not only fails to justify resting this judicially imposed prophylactic measure on such a slender predicate, but also fails to acknowledge or defend the value premises that are implicit in choosing mandatory integration as the particular device to insure against future violations. In any event, his theory, like any other prohibitory theory in this context, needs embellishment to explain why the intervening choices of blacks do not assure us that the defendant is not responsible for the segregated pattern. Dworkin fails to provide this explanation.

34. Green, 391 U.S. at 438 n.4; see id. at 440. 
an antidiscrimination remedy. Having violated the Constitution by enforcing a system of de jure segregation, New Kent County's obligation went beyond refraining from new acts of purposeful segregation: " " $[T]$ he court has not merely the power but the duty to render a decree which will so far as possible eliminate the discriminatory effects of the past as well as bar like discrimination in the future." "35 The old dual school system must be "dismantled," "disestablished"; school boards "operating state-compelled dual systems" are "charged with the affirmative duty to take whatever steps might be necessary to convert to a unitary system in which racial discrimination would be eliminated root and branch." 36 This corrective regime, the Court says, requires a rejection of freedom of choice. ${ }^{37}$ The problem with freedom of choice is not that it is a new act of purposeful discrimination, as a system of racebased pupil assignments would be; indeed, absent the prior discrimination, freedom of choice would not be impermissible. Why, then, is freedom of choice forbidden during the remedy period?

The Court suggests an answer to this question by identifying the effect of the defendant's discrimination that freedom of choice fails to eliminate: the existence of " 'white' and 'Negro' schools." 38 The remedial goal is to "convert promptly to a system without a "white' school and a 'Negro' school, but just schools." 39 Later cases have suggested two somewhat different meanings to this goal. The first understands the remedial goal to be the elimination of school attendance patterns caused by the defendant's past discrimination: since de jure segregation injured students by arranging pupil attendance patterns to produce "white" schools and "black" schools, the remedy must unravel and rearrange those attendance patterns to purge them of discrimina-

35. Id. at 438 n.4 (quoting Louisiana v. United States, 380 U.S. 145, 154 (1965)).

36. Id. at 437-39. Green consolidates the Court's commitment to the narrow corrective view in desegregation cases, requiring that school segregation be eliminated where it results from the defendant's own discrimination. The Court in these cases has never embraced a broader corrective approach, which would have allowed the courts to remedy segregation resulting from "society-wide" discrimination and provided a broader explanation for its decisions.

37. The Court explicitly declined to hold that freedom of choice could have no place in a desegregation plan. See id. at 439-40. "Although the general experience under 'freedom of choice' to date has been such as to indicate its ineffectiveness as a tool of desegregation, there may well be instances in which it can serve as an effective device." Id. at 440 (footnote omitted). See infra notes I08-48 and accompanying text.

38. 391 U.S. at 435.

39. Id. at 442 . Identification of the effects of the violation obviously shapes the definition of remedial goals and strategies. As noted above, see supra note 13 and accompanying text, the defendant's longstanding segregation is likely to have had many kinds of effects; and if all effects are not curable by the same strategies, the identification of those effects that will be the focus of the remedy becomes a critical choice. The basis for this choice may not be self-evident from remedial principles alone. See infra notes 152-57 and accompanying text. 
tion's design. ${ }^{40}$ A second version of the remedial goal requires the elimination of the "racial identity" that the school board's prior discrimination gave the schools. De jure segregation injured students by assigning them to schools identified or branded as "for blacks" or "for whites," and the remedy must change this identity. ${ }^{41}$

Whichever way the remedial objective is understood, there remains the question of why that objective is not achieved by the free choice of students. Although a system of racial assignments and the gerrymandering of school zones obviously affects attendance patterns, why is not the racial pattern attributable to the school board's past discrimination eliminated by the attendance pattern that a system of free choice produces?42 While an odious and insulting racial brand or identity attaches to a school when the govermment designates it "for blacks only" and keeps blacks from attending the "white" school, is not that odiousness eliminated if blacks have the choice to go to the previously allwhite school, even if eighty-five percent choose to stay where they are? Far from reflecting a stigmatic branding by the government, is not any remaining racial identity a consequence of the unencumbered preferences for racial clustering by blacks themselves? Unlike some distributive conceptions, the corrective conception does not condemn racial clustering in and of itself, so why should clustering that results from choices, rather than government assignments, be prohibited by the equal protection clause? ${ }^{43}$ Why are the choices of blacks not determinative?

1. The Concept of Tainted Choice. - The basic problem with the freedom of choice plan is that choices are constrained by discrimination and its effects. When discrimination has occurred, choices are not free in the way that the corrective conception requires, and the effects of past discrimination are perpetuated. Insofar as discrimination may affect choices, I will call these choices "tainted." Choices, of course, are never really completely free; they are always constrained in some way. Moreover, and not surprisingly in a liberal society, our Constitution is broadly tolerant of choice-based distributions, even where choices are

40. See, e.g., Dayton Bd. of Educ. v. Brinkman (Dayton I), 433 U.S. 406, 420 (1977); Keyes v. School Dist. No. 1, 413 U.S. 189, 211 (1973).

41. See, e.g., Columbus Bd. of Educ. v. Penick, 443 U.S. 449, 460-61, 462 n.11, 465-68 (1979).

42. One cannot directly apply here a common argument used against policies of neighborhood assignment following an era of de jure segregation-that assignment of students to the school closest to their homes would perpetuate effects that prior school segregation had on the racial composition of neighborhoods. See Keyes v. School Dist. No. 1, 413 U.S. 189, 202-03 (1973); Swann v. Charlotte-Mecklenburg Bd. of Educ., 402 U.S. $1,20-21$ (1971).

43. It is not sufficient to say that pupil choice rarely plays a role in pupil assignments or in the educational process as a whole. This might suggest that students do not have a right to choose their schools, but Green says that the freedom of choice system is impermissible. 
constrained. But this only highlights the distinctive force of the corrective conception of antidiscrimination law: without making a general challenge to the justness, fairness, or nonexploitiveness of distribution systems based on individual choice, it identifies a specific type of constraint on choice that does offend the Constitution-the government's intentional racial discrimination. Furthermore, it establishes that a choice system is deficient not only when the government's intentionally discriminatory actions directly block people's choices, but also when that discrimination and its continuing effects constrain choices and skew the choice-making process. Where a choice system is "tainted" in this sense, it presumptively does not remedy the violation: the racial identification of the schools has not been purged and attendance pattern effects of the violation have been perpetuated.

To appreciate fully the various ways in which the government's intentional discrimination can constrain choices, one must realize that choices involve both objects to be chosen and people who choose. Discrimination can affect each, producing interrelated constraints of both an external and internal sort: it can limit the external objects available to be chosen (or reduce their appeal), and it can produce internal constraints which inhibit the people choosing. A choice system of the sort used in New Kent County is tainted in these interrelated ways-tainted by the very discrimination ostensibly to be cured-and for that reason fails to cure the violation.

a. Restricted Options. - The most obvious constraint is that discrimination shapes the set of schools from which choices are made. The rhetoric of free choice can mask the fact that the chooser is not allowed to have whatever he wants; in fact, his choice of school must be made from a finite "opportunity set." While the fact of limited options does not by itself create a constitutional problem, freedom of choice is problematic here because the range of available choices is defined and limited by discrimination.

Most significantly, the schools among which students are to choose already have a racial identity resulting from the school board's discrimination. Racial identity may derive from a school's sharply segregated student population at the moment of choice-a concrete vestige of the regime of de jure segregation. It may derive from the racial composition of the school's faculty and alumni. It may derive from the schools' names: the "white" school in New Kent County was called the New Kent School, reflecting its status as the official white school, and the "black" school, called the George W. Watkins School,44 turns out to have been named after a local black pastor and school principal, ${ }^{45}$ thereby confirming its identification as the school for the black community. ${ }^{46} \mathrm{Ra}-$

44. Green, 391 U.S. at 432.

45. Who's Who In Colored America 538-39 (G. Fleming \& C. Burckel eds. 7th ed. 1950).

46. Cf. Vorchheimer v. School Dist., 532 F.2d 880, 881 (3d Cir. 1976) (all-girls high 
cial identity may derive simply from an ingrained public awareness that a school has long been a "white" school or a "black" school.47 (Indeed, in Green the very fact that there were two schools rather than one was a vestige of past segregation.) In short, students are not offered a choice of "desegregated" schools from which effects of the defendant's intentional discrimination have already been purged; instead, their choices are restricted to schools already having a racial identity caused by the defendant's discrimination. Such a restriction not only limits the available choices, but also channels them. Since both blacks and whites are probably reluctant to attend a school already identified as a place for people of a different race, the polar racial character of the options is likely to lead blacks to choose the previously black school and whites the previously white school, ${ }^{48}$ thereby perpetuating segregation. ${ }^{49}$

The Supreme Court in Green did not discuss the ways in which choices were constrained by characteristics of the options presented. However, even lower courts generally approving freedom of choice had recognized one factor: the racial composition of the faculties and staff of the previously segregated schools. If the faculties remained segregated, and the schools were racially identified to that extent, the choice system would be deficient. ${ }^{50}$ Thus, as a condition of upholding a free-

school called Girls High, all-boys high school called Central High), affd by an equally divided Court, 430 U.S. 703 (1977). Other features that might give schools an ingrained racial character include such things as school decorations (for example, a prominent display of a confederate flag), trophy-case photographs of former student heroes (only one race because of prior student composition), curricular features oriented to one race, or institutional lore linked to one race. Such features do not simply give the school an identity, but may also make it less attractive to students of the "other" race.

47. See, e.g., Keyes v. School Dist. No. 1, 413 U.S. 189, 196 (1973) (definition of segregated school includes community "attitudes toward the school").

48. This is so even though the future racial composition of the student body in particular schools is itself to be determined by the choice system. Choices are channelled by conditions at the time choices are made, not after. In any event, as discussed infra notes 63-65 and accompanying text, pupils do not know at the time of choice what others are choosing, so the future student composition of the schools is unknown; this itself is likely to deter choosing the traditionally "other race" school.

49. In a situation like New Kent County, the schools in the opportunity set probably display other choice-constraining effects of discrimination in addition to racial identity. For one thing, at the time of choice, tbe traditionally black schools probably suffer the effects of having traditionally received fewer government resources for educational facilities and programs. Even whites who are willing to attend a school previously identified as a "black" school are unlikely to choose an inferior school, and therefore disparity among "white" schools and "black" schools is likely to perpetuate segregation at the traditionally black schools. See Plaquemines Parish School Bd. v. United States, 415 F.2d 817, 831 (5tb Cir. 1969). In addition, segregated schooling may well bave produced disparities in educational achievement between students currently attending the different schools. People of both races may prove reluctant to choose "other race" schools where the achievement levels of students may be out of line with their own. Once again, the options available for choice are shaped by segregation and probably contribute to segregative choices.

50. See, e.g., Coppedge v. Franklin County Bd. of Educ., 394 F.2d 410 (4th Cir. 
dom of choice plan, these courts required integration of faculties. But the logic of this position also requires elimination of the other tainting features of the opportunity set, including other determinants of the schools' racial identity, as a precondition of a sufficiently free choice system. To be untainted by discrimination, a choice system must provide options for choice that do not reflect effects of discrimination, and this is impossible if at the time of choice the schools in the opportunity set already have a racial identity created by de jure segregation.

b. Duress. - Another reason to distrust the choice system in Green was the probability that choices were deflected by actual or feared duress from those hostile to desegregation. A freedom of choice plan makes individual blacks and whites-not the government-responsible for any integration that occurs and therefore invites others to blame them and make them the targets of hostility. Indeed, since a choice system allows an individual to retreat from an integrative choice or to refrain from making it altogether, such a plan provides incentives for such duress. Threats, reasonable fear of retaliation, or simply predictable discrimination within the traditional white school may effectively coerce blacks to "choose" to stay in the black school.51

When choices are coerced or discouraged in this way, a choice system is plainly unable to eliminate the effects of de jure segregation from the schools. Coercion engaged in directly by public officials, of course, is new unconstitutional racial discrimination. But a choice plan fails to satisfy corrective requirements even where the coercion comes from private parties, at least where this private action has been encouraged by the defendant or reflects attitudes partly shaped by the defendant's segregative practices. ${ }^{52}$ When private citizens opposed to

1968); Clark v. Board of Educ., 369 F.2d 661, 669-70 (8th Cir. 1966); Kier v. County School Bd., 249 F. Supp. 239 (W.D. Va. 1966); HEW Revised Statement, supra note 19. In Green itself, the Fourth Circuit had upheld the basic freedom of choice plan but had required a timetable for faculty desegregation as a "related point." Bowman v. County School Bd., 382 F.2d 326, 327, 328-30 (4th Cir. 1967) (companion case to Green).

51. In a footnote to its opinion, the Supreme Court quoted a passage from a statement by the United States Commission on Civil Rights reporting the existence of this coercive fear of retaliation in southern and border states, but then added, "we neither adopt nor refuse to adopt" these views. Green, 391 U.S. at 440 n.5.

52. See, e.g., Coppedge v. Franklin County Bd. of Educ., 394 F.2d 410 (4th Cir. 1968) (ordering school board to abandon choice plan because of duress). Even lower courts that had approved choice remedies emphasized that they could not do so if there were evidence of coercion. See, e.g., Bowman v. County School Bd., 382 F.2d 326, 327-28 (4th Cir. 1967); United States v. Jefferson County Bd. of Educ., 372 F.2d 836, 890 (5th Cir. 1966), aff', 380 F.2d 385 (5th Cir.) (en banc), cert. denied, 389 U.S. 840 (1967); D. Bell, supra note 4, at 387, 411; cf. United States v. Farrar, 414 F.2d 936, 939 (5th Cir. 1969) (enjoining private "interference and coercion" of blacks exercising rights under a freedom of choice plan). These cases can even be read to hold that a choice remedy implementing coerced choices is unacceptable regardless of whether there is a finding that the government has in some sense caused the coercion. Cf. City of Cleburne v. Cleburne Living Center, 105 S. Ct. 3249, 3259 (1985) (The government "may not avoid the strictures of [the Equal Protection] Clause by deferring to the wishes 
desegregation coerce others in places like New Kent County, they undoubtedly express attitudes to which prior segregation has contributed and seek to perpetuate conditions to which de jure segregation has accustomed them. ${ }^{53}$

c. Distorted Attitudes. - Another way in which effects of past segregation may affect choices is an internal constraint that I will call distorted attitudes. The freedom to choose in Green was not simply exercised under skewed conditions for making choices, where options were restricted by racially identified schools and made unappealing by coercive tactics; it was also exercised by people who themselves had been shaped by discriminatory conditions over the years. A long regime of de jure segregation may skew attitudes, tastes, and perceptions of those exercising choice, and thereby inhibit or channel their choices even though they are now formally free to go to any school. These effects of discrimination distort or preclude the chooser's consideration of the actual benefits and costs (including educational benefits and costs) of going to one school or another. The chooser comes to view the options as more limited than they really are.

These internal constraints can affect the choices of both whites and blacks, with interactive effects within the school system. Whites may refuse to attend formerly black schools hecause their community's history of school segregation has led them to expect that a "white" school is their proper place. ${ }^{54}$ Even though blacks retain the opportunity to attend a white school and receive a less segregated education, as long as whites refuse to attend previously black schools, the black schools will remain all black, and black children will be able to secure a less segregated education only by choosing to change schools and being

or objections of some fraction of the body politic. 'Private biases may be outside the reach of the law, but the law cannot, directly or indirectly, give them effect.' ") (quoting Palmore v. Sidoti, 446 U.S. 429, 433 (1984)).

53. Significantly, a requirement that we look beyond the choices of individuals when discrimination has deterrent effects is a feature of employment discrimination cases as well as school cases, although this common thread has not been recognized. At the violation stage in employment litigation, the courts have insisted upon looking beyond the representation of minorities and women in the applicant pool as the appropriate benchmark in measuring whether the employer has discriminated, and at the remedy stage the courts have required strong recruitment steps. The basic reason is that the employer's applicant pool may "not adequately reflect the actual potential applicant pool, since otherwise qualified people might be discouraged from applying" as a result of the employer's known record of discrimination. Dothard v. Rawlinson, 433 U.S. 321, 330 (1977); see Teamsters v. United States, 431 U.S. 324, 365 (1977).

54. Cf. Armstrong v. O'Connell, 463 F. Supp. 1295, 1309 (E.D. Wis. 1979) (school segregation "taught lessons of racial prejudice and hostility which molded and reinforced prejudicial attitudes [that] influenced . . . housing decisions," and a school segregation remedy properly seeks to cure reciprocal effects of this housing segregation on school attendance patterns). For discussion of some other possible reasons whites might decide not to attend traditionally black schools, see Gewirtz, supra note 15 , at 633-35. 
unequally burdened with dislocations. ${ }^{55}$ The latter fact is not only a problem in its own right, but is also likely to discourage blacks further from leaving their traditionally segregated schools.

While the possibility of tainted white attitudes is significant, the choices of blacks may also be the product of distorted attitudes. It is commonly recognized that true equal opportunity is impossible as long as past discrimination has led to deficient education and skills, but discrimination may burrow even more deeply into the self, affecting psychology as well. Discrimination may distort belief (I believe that what is better is really worse), and it may weaken will (I know what is better but choose what is worse). The Court in Brown I recognized as much when it observed that segregation may affect the "hearts and minds [of blacks] in a way unlikely ever to be undone."56 Among these effects is the possibility that victims of discrimination may have internalized the perspective of the discriminator that they are unworthy and belong in a separate place; some of the beliefs, values, and stereotypes underlying the discriminator's behavior may come to be accepted by victims, shaping their own understandings and expectations. ${ }^{57}$ A related possibility is that victims of discrimination will adapt to the unavailability of certain options by concluding that they do not really want them; their preferences adjust to reduce the "cognitive dissonance" of wanting what they cannot have. ${ }^{58}$ As a result, when given the opportunity to choose schools under a freedom of choice plan, they may choose to stay in "black" schools because they have adapted to the regime of discrimination or have accepted the segregationists' conception of their place. Choice systems that give effect to these constrained choices do not end government responsibility for the segregated pattern; a school system

55. See J. Hochschild, The New American Dilemma: Liberal Democracy and School Desegregation 74 (1984). The choices of whites to avoid blacks may also have the harmful effect of exacerbating blacks' sense that they are being viewed as inferiors.

56. Brown v. Board of Educ. (Brown I), 347 U.S. 483, 494 (1954).

57. See Castaneda v. Partida, 430 U.S. 482, 503 (1977) (Marshall, J., concurring); J. Ely, Democracy and Distrust 257 n.96 (1980); Arons \& Lawrence, The Manipulation of Consciousness: A First Amendment Critique of Schooling, 15 Harv. C.R.-C.L. L. Rev. 309, 323 (1980); Howard \& Hammond, Rumors of Inferiority, The New Republic, Sept. 9,1985 , at 17 . Somewhat analogous issues have been analyzed in recent writings about feminism, in the context of discussions about "consciousness raising" and "false consciousness" among women. See, e.g., Sher, Our Preferences, Ourselves, 12 Phil. \& Pub. Aff. 34 (1983); MacKinnon, Feminism, Marxism, Method, and State: An Agenda for Theory, 1982 Signs 515, 519-520, 531; McWilliams, Contemporary Feminism, Consciousness Raising, and Changing Views of the Political, in Women in Politics 157, 162-64 (J. Jaquette ed. 1974); Rhode, Equal Rights in Retrospect, $1 \mathrm{~J}$. Inequality \& L. I, 46-47 (1983).

58. See 1. Berlin, Four Essays on Liberty 139-40 (1969); L. Festinger, A Theory of Cognitive Dissonance (1959); see also J. Elster, Sour Grapes: Studies in the Subversion of Rationality 109 (1983) (criticizing allocation by preferences when those preferences are caused by people's exclusion, even though "for the utilitarian there would be no welfare loss"). Some people, of course, may respond to deprivation by excessively wanting what they cannot have. 
shaped by preferences that are themselves shaped by a discriminatory school system has only the virtue of consistency.

To be sure, a black's preference to go to school with people having a common racial background cannot automatically be characterized as a tainted preference reflecting a negative self-conception or an adaptation to the defendant's discrimination. Among other possibilities, ${ }^{59}$ that preference might reflect a positive cultural identification and racial pride. After all, as noted earlier, the corrective conception neither requires integration as a permanent distribution nor predicts that blacks would choose it. A person may fight being ordered to remain in a separate place and yet prefer to be separate when given the choice; compelled separation is an insult and an act of domination, but chosen separation may reflect pride and a commitment to group self-determination. The prospect of trying to distinguish this form of separatist sentiment from the phenomenon of distorted attitudes suggests, of course, how difficult it is to work with the latter idea. The difficulties are especially great because distorted attitudes, as an internal constraint, are far harder to identify than more objectively measurable taints such as restricted options. ${ }^{60}$ There are substantial reasons, in other words, to forgo reliance on the idea of distorted attitudes-especially since it is probably unnecessary as a practical matter, given that taints in the other categories would almost surely accompany it.

But taking the corrective conception seriously requires us to be concerned about all harmful effects of discrimination, whatever their genus, and it would be a mistake to completely ignore the possibility that discrimination can distort attitudes. In 1968, in the period shortly after the regime of de jure segregation in New Kent County-a regime that had long branded blacks as inferiors to be kept in their inferior, racially-identified schools-it was plausible to believe that distorted attitudes were at work. Plaintiffs in fact made this argument. ${ }^{61}$ Whether or not working with the concept on a case-by-case basis is practical, recognizing the general phenomenon is an essential part of understanding why we should distrust using a choice remedy to eliminate

59. A black's choice to attend the traditionally black school might reflect the other tainting effects of the defendant's discrimination already discussed, see supra notes 42-53 and accompanying text, effects of "society-wide" discrimination unconnected to the defendant's discrimination (and therefore not cognizable under the narrow version of the corrective approach), or a reasonable assessment of transition costs.

60 . See infra note 92 . Of course, analogous problems are surmounted when courts determine whether a confession or plea is voluntary or whether a person is competent to make certain decisions, and internal states of mind are routinely assessed by courts in deciding whether actions reflect discriminatory intent or criminal mens rea. As discussed more fully below, however, serious empirical difficulties may lead to serious misapplications of the corrective approach. See infra notes 181-220 and accompanying text.

61. Brief for the Petitioners at 22-23, Green v. County School Bd., 391 U.S. 430 (1968); see Memorandum for the United States as Amicus Curiae at 6-7, Green. 
state responsibility for segregated patterns and racial identification of schools.

d. Information and Coordination Problems. - By confining people to schools with others of their own race, de jure segregation also limits the information that whites and blacks receive about people of other races and about integrated education itself. Such information, or the lack of it, is highly relevant when a freedom of choice system is implemented. Because of past segregation, choosing to stay put has the attraction of being "the known" and choosing to attend a school with people of another race has all the deterring uncertainties of "the unknown." For some, the challenge of the new world may beckon, but for many, the skewed information that is one of segregation's legacies will inhibit choices for integration. It is a telling fact that recent studies show convincingly that peoples' views about integration become much more positive after they have experienced it than before. ${ }^{62}$ A choice system gives effect to the limited understanding that is rooted in a segregated experience and thereby perpetuates both segregation and the preconditions for further segregative choices.

The information problems are compounded by the fact that individual preferences in this context are so thoroughly interdependent. A person's preferences are linked to those of others in various ways. For one thing, a person may not be able to secure what he wants independently of what others do. Consider, for example, a black who prefers to attend a school that contains a certain minimum percentage of black students. This preference cannot be satisfied by his choice alone; to secure what he wants requires others to act in a certain way. Indeed, what this person wants may depend upon what others do. He may prefer an "integrated" school over a "segregated" one if, but only if, the "integrated" school has a minimum percentage of blacks. If too many other blacks choose against integration, he would prefer to join them. More specifically, his assessment of the burdens of desegregation is affected by whether the burdens are endured individually or along with others. Widely shared burdens are more tolerable than those borne by only a few individuals. Put more grandly-but perhaps quite aptly in the context of desegregation-what I do for myself alone may be different from what I do when I feel part of a shared historical process. ${ }^{63} \mathrm{~A}$ choice remedy like New Kent County's simply has no way of coordinating these interdependent preferences. In a real sense, choices are made from unknown options-options that are themselves shaped by the very choices to be made. A person cannot select the racial mix he prefers because that option can exist only if other people make as yet

62. See J. Hochschild, supra note 55 , at $182-87$.

63. Indeed, the very idea that issues are "individual" not only influences what preferences are, but also the settings in which preferences are made and satisfied. 1 doubt that the civil rights movement in the 1950's and 1960's would have developed and taken the forms it did if the participants had seen the issues as simply individual ones. 
unmade choices in a certain way. ${ }^{64}$ For these reasons, a choice system that might appear to vindicate individual preferences will have difficulty doing so. Indeed, a mechanism of social decision, rather than "free choice," may be necessary to vindicate certain preferences. ${ }^{65}$

In light of corrective principles, the interdependence of choices is significant because it exacerbates the tainting effects of de jure segregation. It does so in several ways. First, interdependence means that no individual can act by himself to secure attendance at a school whose composition is unaffected by taints. As long as someone else's choice is tainted, the school an individual chooses (and therefore the individual's own choice) will be tainted too. Second, because choices are interdependent, ignorance about the simultaneous choices of others is likely to lead both blacks and whites to choose to remain in their separate schools. If, as seems likely, most blacks will be reluctant to attend a previously white school unless they are convinced that a significant number of other blacks will also attend, and if most whites will be reluctant to attend a previously black school absent other whites, uncertain information is not outcome-neutral. Rather, we can predict a "replication of the status quo"-a segregated pattern. Third, to the extent that students do know about the choices of other students, and those other choices are decisions not to attend the previously "other race" school, there is likely to be a ripple effect of inhibition. Thus, if any substantial number of choices are tainted in the sense already described, then that taint will spread to affect the choices of others, tainting (or further tainting) their choices as well.

2. The Remedial Insufficiency of Liberty and the Duty to Integrate. - We may now generalize some. From the perspective of remedial theory, the choices in Green were tainted because of the starting point: racially identified schools and the many other effects of a regime of segregation. Preferences and choices were skewed by established institutions, established patterns of behavior, established information, and an established psychology, that were rooted in discrimination. It simply would not be plausible to explain the segregated pattern as a product of autonomous choices that were independent of discriminatory forces. Because of the tainting influences, there was a distortion in the formation and implementation of choices that is analogous to "market failure" in the economic realm. In this respect my critique of desegregation remedies based on freedom of choice indicates some deficiencies that may exist in choice- and preference-based allocation schemes more generally, outside the discrimination field. But the argument here is a

64. In theory, it would be possible to solve some of these problems by devising a choice plan under which people would make conditional choices ("I will attend this school if the racial mix is at least $30 \%$ black."). Such a mechanism did not exist in New Kent County and has not existed in any choice plan I know of.

65. See R. Hardin, Collective Action (1982); T. Schelling, Micromotives and Macrohehavior (1978). 
sharply limited one, since the context is constitutional law. Although the Constitution is generally untroubled by the fact that preferences are affected by starting points and past history, the critical feature in the desegregation context is the presence of the fourteenth amendment. Its antidiscrimination norms, implemented by corrective principles, require that we be deeply suspicious of the defendant's use of a choice system in which the starting point is significantly shaped by the defendant's own history of segregation. Given that history, simply giving students a choice in New Kent County did not " 'determin[e] admission . . . on a non-racial basis." "66 Thus, the choice plan was unacceptable.

Green's prohibition on freedom of choice is a transitional remedial rule. A choice system is prohibited because it perpetuates, rather than eliminates, the continuing effects of proven discrimination. But choice is not a constitutionally forbidden method of pupil assignment at all times and in all contexts. Absent current or past discrimination by the defendant, freedom of choice would be a permissible method of assigning students, even if it produces a segregated pattern. The corrective conception can condemn a choice plan only temporarily, during a transition period until the violation is remedied. 67

Mild tinkering with the starting point does not end the corrective prohibition on choice. In Monroe v. Board of Commissioners, ${ }^{68}$ a companion case to Green, the defendant had ostensibly shifted from a regime of de jure segregation to one of geographically-based attendance zones, but as part of the plan it allowed any student to transfer from his zoned school to a school of his choice. All the white students and most black students exercised their "transfer" option and enrolled at schools previously identified as schools for their race. The mere creation of racially-neutral attendance zones that seemed to put the state's coercive authority behind the creation of integrated settings did not really change the starting point. Students "transferred" out of schools they had never attended or had attended only briefly. In rejecting the plan, the Court explained that students were "permitted . . . to return, at the implicit invitation of the Board, to the comfortable security of the old, established discriminatory pattern." 69 As the Court seemed to recognize, the tainting elements in the situation-the racial identification of the schools as well as other elements described above-had not been adequately transformed before the transfer option was made available.

But my analysis suggests a deeper point: the freedom of choice remedy in Green was fundamentally unsuitable because it offered simply a "liberty" remedy for a wrong that denied both "equality" and "liberty." The wrong of segregation is not merely that it denies individuals

66. 391 U.S. at 432 (quoting Brown v. Board of Educ. (Brown II), 349 U.S. 294, 300-01 (1955)).

67. See id. at 441.

68. 391 U.S. 450 (1968).

69. Id. at 459 . 
the liberty to choose, but that it establishes a system of group subordination in which racially-identified institutions proclaim black inferiority and maintain blacks' second-class status in the community. Because of the nature of the past discrimination, effective remedies for individuals cannot be furnished by purely individualistic solutions such as letting students choose their schools one-by-one; individualistic solutions misunderstand the remedial right. A black child's remedial right is not a right to attend the previously white school; it is a right to attend a desegregated school-an institution that is not racially identified, an institution whose attendance patterns do not reflect the regime of past de jure segregation, an institution that is not an element of a segregated system. ${ }^{70}$ That individual right simply cannot be fully achieved in isolation from what happens to other children: the effectuation of individual rights requires coordinated systemic action. The remedy for a systemwide violation must deal with the school system as a whole. ${ }^{71}$

From this perspective, affirmative steps going beyond mere choice are needed to erase racial identification and other effects of the violation. A few years after Green, in Swann v. Charlotte-Mecklenburg Board of Education, ${ }^{72}$ the Supreme Court made explicit what it had merely implied in Green: the required corrective for systemwide de jure segregation is integration, with busing a permissible tool in achieving integration. Implementing this corrective has remained difficult and controversial, as explored more fully below, ${ }^{73}$ but the basis for the requirement is well established. The integration mandate proceeds from the recognition-still ignored by some commentators ${ }^{74}$ - that effects of past violations persist even after the violations stop. The duty to inte-

70.

[F]or the time immediately after Brown II the concern was with making an initial break in a long-established pattern of excluding Negro children from schools attended by white children. The principal focus was on obtaining for those Negro children courageous enough to break with tradition a place in the "white" schools. . . . Under Brown II that immediate goal was only the first step, however. The transition to a unitary, nonracial system of public education was and is the ultimate end to be brought about ....

391 U.S. at 435-36 (emphasis added) (citation omitted).

71. Professor Herbert Wechsler's failure to see this contributed to his inability to defend Brown 25 years ago. Wechsler, Toward Neutral Principles of Constitutional Law, 73 Harv. L. Rev. 1, 31-35 (1959). For a contemporary version of this failure, see infra note 96 and accompanying text (views of Assistant Attorney General William Bradford Reynolds, Jr.). The objective of Brown was not to secure admission of the individual black plaintiffs to a "white" school, but to dismantle a school system that was constructed on racism. The equality rights of individuals in this situation are interdependent, and therefore the individualism of freedom of choice is fundamentally insufficient. See Marshall, A Comment on the Nondiscrimination Principle in a "Nation of Minorities," 93 Yale L.J. 1006, 1007-08 (1984); Dimond, The Anti-Caste Principle-Toward a Constitutional Standard for Review of Race Cases, 30 Wayne L. Rev. 1, 42-48 (1983).

72. 402 U.S. 1 (1971).

73. See infra notes $85-180$ and accompanying text.

74. See, e.g., R. Wolters, supra note 4 , at 275-77. 
grate is derived from the Court's understanding of the relevant effects of past de jure segregation that the remedy must eliminate: racially concentrated attendance patterns and racially identified schools. Mandatory integration unravels those attendance patterns and erases the schools' prior racial identities. ${ }^{75}$ In short, it implements a black child's individual remedial right to attend a desegregated school. The precise racial mix of students necessary to achieve these objectives in particular cases may be contested (particularly in cases where the scope of the violation itself is uncertain), and there can be certain cost tradeoffs, ${ }^{76}$ but some race-conscious pupil reassignment has been deemed necessary to eliminate the identified effects of the violation. ${ }^{77}$ The courts have suggested different ways of determining the minimally appropriate racial mix, but it is clear that this minimum is not, by definition, the number of blacks and whites who would select integration under a choice system like New Kent County's and not necessarily the number that would be assigned to schools under a prospectively "colorblind" neighborhood assignment system. Mandatory integration seeks to eliminate effects of the violation that would not be eliminated by a mere prohibition on future segregation or use of neighborhood assignments or adoption of a free choice system.

Like the prohibition on freedom of choice, the requirement of integration is a transitional rule, justified by the courts under a corrective theory rather than a distributive or prohibitory theory. ${ }^{78}$ A segregated condition-a simple failure to have integrated schools-does not by itself violate the Constitution; but even though the Constitution does not impose a general duty to integrate the schools, it does require integration as a transitional remedy. The distinctive character of this corrective theory of integration is illustrated by a well-known passage in the district court opinion in Briggs $v$. Elliot, ${ }^{79}$ decided after the Supreme Court's remand in the Brown cases: The Constitution "does not require

75. Gewirtz, supra note 15 , at 646-47. Integration has been linked to a range of equality goals: countering the symbolic affront of placing blacks in segregated institutions; promoting interracial contact; creating a mechanism that assures equal distribution of resources among schools; and reducing achievement gaps between whites and blacks, especially educational achievement gaps. See, e.g., J. Hochschild, supra note 55.

76. See Gewirtz, supra note 15, at 598-606; infra note 116 .

77. Race consciousness as a part of these transitional desegregation remedies has usually not been as controversial as race-conscious affirmative action in employment or university admissions. There may be at least two reasons for this: (1) In the desegregation context, race consciousness simply determines which school tbe person attends, and no one is denied the opportunity to attend school; and (2) the burdens of achieving corrective goals are rather evenly distributed. In the affirmative action context, the burdens are often denial of a job or higher education, and a relatively small number of people are singled out to bear those burdens.

78. See supra notes $25-33$ and accompanying text (discussing possible justifications for integration under a distributive or prohibitory theory).

79. 132 F. Supp. 776 (E.D.S.C. 1955) (per curiam). 
integration. It merely forbids discrimination." 80 The Briggs court faltered because it saw only two possible meanings of the equal protection clause-it either "require[s] integration" or "merely forbids" new discrimination. In fact, however, the Constitution does something less than the former and something more than the latter. Briggs failed to distinguish between end-state and corrective rules. The Briggs dictum failed to recognize that even if the Constitution does not "require integration" as a permanent end-state matter, it may "require integration" as a transitional remedial policy. Simply "forbid[ding] discrimination" in the future does not eliminate the continuing effects of the admittedly "forbid[den] discrimination" that has already occurred. Like other race-conscious affirmative action, judicially mandated integration remedies are supposed to be temporary; they are designed to undo effects of past segregation and then terminate. ${ }^{81}$ Once the transition to an endstate free of the effects of the defendant's segregation is completed, the duty to assure integration ends, and any nondiscriminatory assignment scheme is permissible.

While the Supreme Court has not justified integration in terms of freedom of choice-choice is certainly not a constitutionally required method of pupil assignment once the effects of past segregation have been eliminated-my discussion of tainted choices suggests why requiring integration for a period of time is a plausible precondition to having an untainted post-violation choice plan. Integration is necessary to eliminate effects of the defendant's past segregation that would taint choices-most obviously, to eliminate the preexisting racial identifiability of the schools. To be untainted, choices must be made from among schools that are not racially identified; the segregated arrangements must be actually disestablished and attendance patterns transformed. ${ }^{82}$ Indeed, in order for the racial identity of the schools to be transformed, integration will have to be maintained for a period of time sufficient to change public perceptions and understandings. Integration, in short, is a transitional prerequisite to a constitutionally permis-

80. Id. at 777. This case was one of the four other cases argued before the Supreme Court and decided along with Brown. The "Briggs dictum" was widely quoted during the 1950's and 1960's, see J. Wilkinson, From Brown to Bakke-The Supreme Court and School Integration: 1954-1978, at 81-82, 113 (1979), but was explicitly rejected by the Supreme Court in Keyes v. School Dist. No. 1, 413 U.S. 189, 200 n.11 (I973). Raymond Wolters recently has urged its revival in his controversial book. See R. Wolters, supra note 4, at 6-7, 138-39, 288.

81. Pasadena City Bd. of Educ. v. Spangler, 427 U.S. 424 (1976); see infra notes 193-220 and accompanying text.

82. The experience of integration also can help to eliminate other tainting features. Thus, over time, it can dispel attitudes held by blacks in the community that their proper place is in a separate school; it can change the conditions wbich create a reasonable fear of retaliation and future discrimination (both by assuring a sufficient number of otherrace students to secure "safety-in-numbers" and by improving interracial understanding); and it can increase the flow of information about other-race students and schools. 
sible use of a choice system that fails to produce integration..$^{83}$

A paradox may seem to lurk in this understanding of the remedial imperative: If blacks might choose to cluster together under a constitutionally acceptable choice plan in the end-state, how can a choice remedy producing that configuration be unacceptable during the remedy period? If pluralism in the end-state might include all-minority schools, ${ }^{84}$ why are such schools prohibited during the remedy period? The answer is that we distinctively distrust the choice of a separated pattern following a regime of de jure segregation. To reject a distributive rule that would make integration a permanent end-state requirement-to recognize pluralist possibilities-does not require us to endorse a separation that continues the separatism imposed by the school board. What the government must do is dismantle the institutions of segregation that it created. It must transform the patterns that signal its design, erase what it created, and thereby allow a new pattern to emerge. Perhaps the pattern that emerges will eventually be the same as existed under the regime of de jure segregation, but unless there is a remedy period of transformation that erases the school board's design, there can be no confidence at all that the future arrangement is essentially free of past wrongs.

In a sense, then, the corrective effort may overshoot the end-state. The effort to eliminate effects of past discrimination may create an arrangement that is different from the one that may ultimately emerge from future nondiscriminatory policies. In particular, by mandating integration during the remedy period, the government creates an integrated starting point for future nondiscriminatory policies, and this may establish some bias toward integrated end-state distributions. But once there has been a regime of de jure segregation, no absolutely neutral starting point is possible. Because of the thrust of past wrongs, there must be a counterthrust, which will inevitably establish momentum in a new direction. Unavoidable momentum, however, is different from a permanently mandated requirement. We must respect the pluralist possibility for the future if we are to be faithful to the limited nature of the corrective idea. That respectful reticence about future possibilities is reflected in the commitment that the remedial policies are only temporary, that they will counter the effects of past discrimination and then terminate-that the future will be free of both the defendant's wrongs and the court's corrective requirements.

83. This also clarifies why Professor Thomas Sowell is wrong when he says that deciding whether the New Kent County school system remained "'segregated' or not depended entirely on whether segregation was defined in terms of opportunity or results." T. Sowell, Civil Rights: Rhetoric or Reality? 67 (1984). The proper response to Sowell is that in order to create conditions that will provide equal opportunity-to create conditions where unlawful segregation can be defined independently of results-it is necessary to go through a transformative transition period where the focus is on results.

84. See J. Hochschild, supra note 55, at 189-90; M. Walzer, Spheres of Justice: A Defense of Pluralism and Equality 223 (1983). 


\section{Freedom of Choice Today}

The teaching of Green endures: the corrective aspiration pervades desegregation cases, and, in its name, the courts have overwhelmingly mandated integration and rejected freedom of choice as a remedy for school segregation. In recent years, however, many people, both white and black, have questioned whether school integration is currently achievable by court order or worth trying to achieve, particularly in light of the costs often entailed. Against this background, the Reagan Administration, a substantial group of commentators, and a number of federal judges have challenged the existing legal framework. They reject the prevailing remedial notion that courts must order pupil reassignments to produce integration, and they embrace freedom of choice as the preferable remedial mechanism. They proclaim, in short, that the teaching of Green is inapplicable today-and in so doing have not only brought school desegregation law to a fateful crossroads, but have raised difficult new questions about the corrective enterprise itself.

Various versions of the "free choice" idea have been proposed. Some urge in general terms that pupils simply be given their choice of schools, while others propose freedom of choice along with other features, such as educational improvements of some form (including the establishment of so-called "magnet schools") ${ }^{85}$ The Reagan Administration initially argned that mandatory integration should be replaced by a choice-plus-educational-improvements remedy that pledged to produce significant integration, but more recently it has settled for stripped-down choice plans lacking significant educational components or significant prospects for integration. ${ }^{86}$

These new choice defenders typically fail to provide a clear theoretical basis for choice remedies, but four different justifications seem to be at work, each deserving separate consideration: (1) Freedom of choice is appropriate to avoid the offensive paternalism of mandating integration. (2) Freedom of choice is appropriate because choices today are already untainted or can readily be untainted. (3) Freedom of choice is appropriate as a means of achieving integration. (4) Freedom of choice is appropriate because it is the best method to achieve a variety of remedial goals, not limited to integration. 87 Some of these argn-

85. See infra notes $105-64$ and accompanying text.

86. See infra notes $140-48$ and accompanying text.

87. For purposes of this Part's discussion of appropriate remedies, 1 assume that there has been a finding of systemwide violation, and therefore I leave to one side the arguments made by some commentators that mandatory integration is inappropriate in particular cases because the scope of the violation shown is too narrow to support a broad, systemwide remedy. See Goodman, supra note 4, at 413; Kurland, Brown v. Board of Education Was the Beginning, 1979 Wash. U.L.Q. 309, 398; accord Columbus Bd. of Educ. v. Penick, 443 U.S. 449, 489, 519-21 (1979) (Rehnquist, J., dissenting). 1 return to some issues about proving the scope of a violation in Part IV infra, but I note here an apparent contradiction in some of these commentators' views: even in the cases where they challenge the findings of violation, they nevertheless would apparently not permit 
ments are stronger than others, but all, I think, should be viewed with skepticism. There is one area, though, where choice plans seem to offer a major opportunity to deal with a hitherto intractable problemthe provision of interdistrict relief-and here I propose their more aggressive use.

\section{A. Choice in Order to Avoid Paternalism}

The new choice defenders have repeatedly sounded a basic philosophic claim: remedies prohibiting freedom of choice and mandating integration are offensively paternalistic. According to Professor Frank Goodman, for example, failing to use a choice system is paternalistic because individual black parents "are at least as likely as the courts" to be right in assessing "what is good for their children," that is, in deciding whether, for them, the benefits of integrated schools outweigh the burdens. Indeed, says Professor Goodman, even if blacks have a right to an integration remedy, a freedom of choice system would simply permit individual blacks to "waive" their rights, and few rights cannot be waived. 88

At the threshold, this paternalism objection has a particularly curious quality in the context of schooling. Quite apart from the desegregation issue, school boards routinely ignore individual choice in assigning students to particular schools and in setting curricular requirements-indeed, in requiring children to go to school in the first place. ${ }^{89}$ Philosophic objections are rarely made to these near-universal

the school board to use a pure neighborhood assignment scheme. Rather, they would require a choice option to be made available to students so that pupils may transfer to schools in which their race is a minority, and they would require the defendant to pay the costs of transportation. See, e.g., Goodman, supra note 4, at 414 . If they reject the view that there has been a systemwide violation with current systemwide effects, by what authority does a court require a school board to allow students a choice and to pay transportation costs for those who exercise the option to attend nonneighborhood schools?

88. Goodman, supra note 4, at 407; see also Tasby v. Wright, 520 F. Supp. 683,733 (N.D. Tex. 1981) ("the imposition of mandatory transportation on minority parents and children who are opposed to such a remedy is unfair and paternalistic"); D. Bell, supra note 4, at 411 (contemporary busing plans could be "as cocrcive and harmful to blacks" as assignment schemes rejected by courts decades ago); Coleman, supra note 4, at 14 ("arrogance of the white liberal, who believes that he knows what is best"); Sowell, False Assumptions about Black Education, in The Fairmont Papers: Black Alternatives Conference, San Francisco, Dec. 1980, at 63, 79 (1981) (we should focus on "freedom to choose," not how people can "fit into someone else's grand design"); Glazer, What is "Voluntary"?, N.Y. Times, Oct. 23, 1981, at A31, col. 2 (courts should get away from the "idea that someone's rights are being limited when he is allowed to select the school he prefers for his children and that his rights are only fulfilled when he is required to send his child to a certain school") (emphasis added); infra notes 96-98 and accompanying text (discussing Reagan Administration's view).

89. Moreover, matters not decided by public officials are usually decided by parents or guardians for the pupil, not by the pupil. Thus, what the student wants is routinely overridden, whether by the government or by parents or guardians. 
compulsions since they involve children, with whom paternalism is usually unobjectionable, and concern the education process, in which the community's interest is usually considered strong. ${ }^{90}$ To say that mandatory integration is offensively paternalistic simply because it fails to effectuate individual choices is an argument that would apply equally to virtually all assignment schemes now used in public elementary and secondary education. It is not a challenge that integrative assignments have a distinctive burden of answering.

If there is anything unique to a paternalism argument in this context, it derives from the way the integration requirement arises. A court is furnishing a remedy for harms suffered by victims of a legal wrong, yet it seems to be overriding the beneficiaries' judgment of their own remedial entitlements. The very wrong being corrected is offensive in part because the government's discriminatory restrictions imposed something on blacks that they did not want, and it would seem at least ironic if the remedy could be characterized the same way. ${ }^{91}$

But my earlier analysis establishes why this reformulation does not really strengthen the paternalism objection. For one thing, a charge of offensive paternalism rests on the premise that individual choice or "waiver" best expresses what a person really wants or what is in his best interests; but the existence of taints resulting from discrimination altogether undercuts that premise. Indeed, when a choice system is used following a history of de jure segregation, many victims are likely to state that their apparent choice is not what they really want. For example, they may choose to attend a previously black school when presented with an opportunity set containing only schools that are already racially identified, but actually prefer to attend an integrated school, which is not in the opportunity set. To liberate their "real"

90. If any burden is on a school to "defend" the near-universal practice of assigning pupils to schools rather than leaving the matter to individual choice (a practice, by the way, which often involves "busing"), various justifications might be offered that have nothing to do with the paternalistic belief that children or their parents are not the best judges of their own interests. For example, a school board might point to administrative and cost savings from its mandatory assignment system; or the value to the community as a whole of assuring heterogeneity within schools (including educational benefits such as preparation for citizenship in a pluralistic society); or the preferences of one category of students for a particular kind of assignment scheme that can be implemented only by ignoring the preferences of another category of students. While a relatively small group of commentators and politicians have urged the introduction of a "voucher" system that would enable students to choose the public or private school of their choice, see, e.g., J. Coons \& S. Sugarman, Education by Choice (1978), it is safe to say that this idea has not swept the country. Significantly, its leading proponents explicitly recognize that their proposal can have only limited application where a school segregation violation must be remedied, since they recognize that an integrated result must be achieved. Id. at 120-22.

91. Arons and Lawrence have observed: "[A] blind pursuit of racial integration, without attention to the values and desires of minority parents, may be as offensive a form of racism as coercive separation and stigmatization of minority parents." Arons \& Lawrence, supra note 57 , at 345 n.110. 
preference-to give them the desegregated school they would like and would choose if it were an option-external intervention is necessary. In this sense, collective action enhances liberty, rather than restricts it. 92

Second, and even more significantly, it is simply irrelevant that some blacks may prefer continued separation, since interfering with their preferences is necessary to effectuate the remedial rights of other black victims. Not every overriding of individual choice is paternalistic. Problems of paternalism arise only when an external authority concludes that an individual is not the best judge of what he really wants or what is in his own best interests. Government action in all fields, however, routinely overrides individuals' choices because doing so is necessary in order.to benefit others-indeed, often in order to vindicate the preferences of others. In such a situation, the criticism of paternalism would be out of place.

And so it is here. Once de jure segregation is shown, children have a remedial right to attend a desegregated school.93 While some blacks may not want to attend a desegregated school, the fact is that more do than do not. ${ }^{94}$ To secure a desegregated setting for these victims-to

92. One category of taint discussed earlier deserves separate comment in light of the paternalism objection. Somewhat distinctive issues would arise if choices were being overridden simply because they were deemed to be the product of "distorted attitudes," see supra notes 54-61 and accompanying text. On one hand, the category of distorted attitudes does describe a basic psychological phenomenon that certainly seems real to many people. Moreover, if people choose a separate school because prior segregation has inculcated an attitude that the separate school is their proper place, or because their preferences have adapted to exclusion, the basic argument for looking beyond the individual's choice seems fully applicable: the premises of deference are undercut, and the corrective conception counsels that courts should not permit a school system to remedy discrimination by giving effect to choices skewed by the very discrimination to be cured.

On the other hand, where the government says it is overriding a choice simply because the choice is the product of distorted attitudes, the chooser may view the government's action as an intrusion on what is subjectively experienced as a taint-free, "real" preference. Moreover, because of the distinctive empirical problems of determining whether a choice is the product of an internal constraint like distorted attitudes, see supra note 60 and accompanying text, there is a greater danger that choices will be overridden not because they are produced by "distortion" but simply because the government disagrees with the substance of the choices made. See infra note 183 and accompanying text. For these reasons, the paternalism objection in the school desegregation context would be sharpened if judicial intervention rested solely on the chooser's "distorted attitudes."

The short answer to these concerns, however, is that intervention will virtually never rest on distorted attitudes alone. After a regime of de jure segregation, choosers will almost always be affected by taints in the other categories-for example, prior segregation will have skewed both the opportunity set and information-and this will fully justify rejection of a choice system without opening up the distinctive paternalism questions posed by the concept of "distorted attitudes."

93. See supra notes 70-71 and accompanying text.

94. See J. Hochschild, supra note 55, at 160 (citing opinion polls). Moreover, as Hochschild notes, to the extent blacks indicate that they do not prefer integrated 
secure their individual remedial right-a court must transform the institutions that these children attend. This may be achievable only by disregarding the preferences of some people who do not want to attend a desegregated school. But that is hardly paternalistic. ${ }^{95}$

This insight also demonstrates what is so misleading about the rhetorical centerpiece of the Reagan Administration's defense of choice, its insistence that "[a]ny students who want to have an integrated education ought to have it, but if there are students out there who do not want an integrated education, we should not be compelling them . . . to have one." 96 This position is internally contradictory. It simply may not be possible to provide an integrated education for those who want it without compelling an integrated education for those who do not. ${ }^{97}$ Indeed, to suggest that a choice system leaves everyone free to have what he wants masks the deeper truth that a choice system is biased to favor the preferences of those who want a segregated setting over those who want an integrated one. ${ }^{98}$

This is not to deny that an integration remedy may impose costs that some individuals reasonably would prefer not to bear. But, at a minimum, these costs and contrary preferences must first be assessed by the court in systemwide terms and evaluated in light of the remedial rights that mandatory integration vindicates for members of the plaintiff class as a whole. One might in the end object to an integration remedy and defend free choice on the ground that not enough blacks want integration or that it is too costly in systemwide terms (arguments I consider below ${ }^{99}$ ), but one cannot simply point to the contrary preferences of some individual blacks as a dead-stop argument against integration on the ground that it is paternalistic.

schools, one must ask why. The indications are that many such preferences reflect factors similar to those I have called taints. See id. at 162-66.

95. Cf. W. Shakespeare, Hamlet, act I, scene iii, lines 19-22:

He may not, as unvalu'd persons do,

Carve for himself, for on his choice depends

The safety and the health of the whole state;

And therefore must his choice be circumscrib'd.

96. N.Y. Times, Feb. 14, 1982, at 35, col. 1 (quoting Assistant Attorney General William Bradford Reynolds, Jr.); see also School Desegregation: Hearings Before the Subcommittee on Civil and Constitutional Rights of the House Comm. on the Judiciary, 97th Cong., 1st Sess. 631 (1981) ("Our remedies will be designed in order to help those kids that want to have an integrated education to have it ... . [W] are not going to compel children who do not want to choose to have [an] integrated education to have one.") (statement of William Bradford Reynolds, Jr.).

97. Given the differing preferences among blacks, it is probably fair to say that any remedial system will frustrate the preferences of some blacks. While this does not mean that any of these remedies is offensively paternalistic, it does suggest that adopting a choice remedy may be as paternalistic as adopting an integration remedy. Certainly to say that a choice system is better for all blacks (rather than some) would be paternalistic.

98. See supra notes $44-65$ and accompanying text.

99. See infra notes I59-164 and accompanying text. 


\section{B. Choice Without Taint}

A more specific but less common defense of contemporary choice remedies in effect maintains that choice plans are untainted or can be made untainted before people choose. These suggestions reflect a basic error, however: they fail to acknowledge the full range of tainting influences. Professor Derrick Bell, for example, explains the rejection of choice in Green by invoking only one tainting element in the picture: "It was feared that black parents would face economic retaliation and possible physical violence." 100 Professor Bell then seems to suggest that freedom of choice should be a permissible remedy unless blacks' "failure [to choose predominantly white schools] is due to coercion or fear of retaliation." 101 This position disregards the other categories of taint discussed above, and therefore ignores ways in which discrimination may still constrain choices even where the fear of violence and discrimination is no longer present (itself an unlikely prospect).

To be sure, taints in some of these categories may sometimes not exist, may have already diminished, or may be reduceable by aggressive remedial steps. For example, if the prospect of using a choice system seems less troublesome today than it did when Green was decided in I968, I suspect it is not so much because the taints of white coercion have largely disappeared, as Bell implies, but because we are less likely to suspect that blacks' choices reflect internalization of the oppressors' perspective or similar distorted attitudes. This reinterpretation of subjective black consciousness is based on a recognition that the separatist impulse today frequently reflects attitudes of affirmative racial identification, racial empowerment, and racial pride, as well as a view that under some conditions today a choice against integration may be an objectively "reasonable" choice. But change in the attitudes of some hardly suggests that distorted attitudes have altogether disappearedand even assuming that they have, the other categories of taint continue to constrain choices and make a choice remedy inappropriate. ${ }^{102}$ Most significantly, as my earlier analysis explains more fully, ${ }^{103}$ it is in fact impossible for the choice-making process to be untainted so long as the schools in the opportunity set start out with an existing racial identity. The segregated starting point must be transformed before choices are made-and no proposed remedy that I know of can do that without requiring integration. ${ }^{104}$

100. D. Bell, supra note 4 , at 410-11.

101. Id.; see N. Glazer, supra note 4 , at 118 .

102. See supra notes $44-53,62-65$ and accompanying text.

103. See supra notes $49-50,63-65,70-71$ and accompanying text.

104. In theory, of course, one could close all the existing schools, build new ones, scramble existing faculties, and eliminate all other indicia of racial identifiability-and then ask students to choose from an opportunity set containing only new schools without any identity, racial or otherwise. As noted below, that is sometimes done with respect to some "magnet" schools, see infra notes 135-38 and accompanying text, but it is 


\section{Choice as a Means to an Integrated End}

Proponents of choice most frequently defend choice as an appropriate means to the admittedly required end of integrating the schools. This view accepts the long-established legal principle that, once de jure segregation is shown, there is a remedial duty to integrate, and it measures the success of a remedial plan by whether an integrated result is achieved. It argues, though, that today a properly structured and vigorously implemented choice system can achieve as much integration as a mandatory reassigument plan. ${ }^{105}$ This view seems the basis for recent lower court decisions that have approved choice mechanisms as the basic means to desegregate school systems in Chicago, Cincinnati, and a number of other cities. ${ }^{106}$ It also appears to have been the defense

totally unrealistic as an approach for the entire school system. So long as the schools in the opportunity set have a history and identity continuous with the regime of de jure segregation, the choice system will be tainted. See also supra note 64 (conditional choices).

Another strategy for untainting choices is theoretically available: not to eliminate the tainting elements directly, but to try to counteract their effects indirectly, compensating for lingering taints by building certain counterweights into the system. Under this approach, for example, magnet schools might be required as part of the choice remedy not simply as a way to "equalize" resources in schools previously shortchanged by discrimination, and not simply as a way to coerce an integrated outcome (the justification offered in the next section), but to indirectly overcome the constraints from tainting influences that remain in the choice plan. Thus, if the preexisting racial identity of the schools contributes $X$ units of inhibition on choices, then magnet elements in a school should provide $X$ units of compensating incentive. Even if plausible in theory, and even assuming costs were not a constraint, this approach seems unworkable in practice, since it is altogether impossible to imagine measuring what indirect counterweights would be sufficient to overcome particular tainting features (such as the existing racial identities of the schools).

105. While there may, of course, be debate about what degree of integration is the legally required result, the argument here is simply that whatever degree of integration is legally required can be achieved through a choice system.

106. See Bronson v. Board of Educ., 604 F. Supp. 68, 75 (S.D. Ohio 1984) (Cincinnati); United States v. Board of Educ., 554 F. Supp. 912, 917, 924-26 (N.D. Ill. 1983) (Chicago). Other recent cases seem to have approved some form of choice plan on this theory. See, e.g., Clark v. Board of Educ., 705 F.2d 265, 272 (8th Cir. 1983) (Little Rock); United States v. Texas Educ. Agency, 679 F.2d 1104, 1110 (5th Cir. 1982) (Port Arthur); Vaughns v. Board of Educ., No. 72-325-K (D. Md. June 30, 1985) (Prince George's County); Flax v. Potts, 567 F. Supp. 859, 874 (N.D. Tex. 1983) (Fort Worth); Arthur v. Nyquist, 514 F. Supp. 1133, 1139 (W.D.N.Y. 1981) (Buffalo); Smiley v. Vollert, 453 F. Supp. 463, 476 (S.D. Tex. 1978) (Galveston), modified sub nom. Smiley v. Blevins, 514 F. Supp. 1248, 1263 (S.D. Tex. 1981). In most of these cases, a choice mechanism was proposed to desegregate all or most of an entire school system. Such cases should be distinguished from situations where an occasional magnet school is used (and upheld) as a desegregation tool, e.g., Hart v. Community School Bd. of Educ., 512 F.2d 37, 54-55 (2d Cir, 1975), or majority-to-minority transfers are used as part of a mandatory integration plan, e.g., Swann v. Charlotte-Mecklenburg Bd. of Educ., 402 U.S. 1, 26-27 (1971).

Choice plans continue to be rejected by the lower courts, of course, even when defended on the means-to-an-integrated-end theory. See, e.g., Davis v. East Baton 
used by the Reagan Administration when it first called for choice remedies to replace mandatory ones. ${ }^{107}$

In theory, this defense of choice is powerful. Green itself condemned New Kent County's plan because it did not "work" and "work now" to eliminate the "black" schools and "white" schools, and the Court explicitly declined to "hold that 'freedom of choice' can have no place in [a permissible] plan." 108 Thus, the holding in Green would not necessarily bar a contemporary choice plan that actually "worked" to produce integration. ${ }^{109}$ Moreover, using choice is not in theory inconsistent with actually achieving an integrated result. Incentives can be manipulated to make a choice for integration more or less desirable.

Rouge Parish School Bd., 721 F.2d 1425, 1437 (5th Cir. 1983); Tasby v. Wright, 713 F.2d 90, 97 (5th Cir. 1983); Kelley v. Metropolitan County Bd. of Educ., 687 F.2d 814, 823 (6th Cir. 1982), cert. denied, 459 U.S. 1183 (1983); Adams v. United States, 620 F.2d 1277, 1295 (8th Cir.), cert. denied, 449 U.S. 826 (1980); Lee v. Marengo County Bd. of Educ., 588 F.2d 1134, 1135-36 (5th Cir.), cert. denied, 444 U.S. 830 (1979); United States v. DeSoto Parish School Bd., 574 F.2d 804, 818 (5th Cir.), cert. denied, 439 U.S. 982 (1978); Morgan v. Nucci, 602 F. Supp. 806, 808-09 (D. Mass. 1985); Hoots v. Pennsylvania, 539 F. Supp. 335, 342-43 (W.D. Pa. 1982), aff d, 703 F.2d 722 (3d Cir. 1983); Keyes v. School Dist. No. 1, 540 F. Supp. 399, 401 (D. Colo. 1982).

107. See Brief for the United States at 5, 9, Davis v. East Baton Rouge Parish School Bd., 721 F.2d 1425 (5th Cir. 1983). For enumeration of some of the main cases in which the Reagan Administration has proposed or agreed to choice plans, see infra notes $145-47$ and accompanying text.

108. Green v. County School Bd., 391 U.S. 430, 439 (1968) (emphasis in original).

The Court went on to state that:

[A]ll we decide today is that in desegregating a dual system a plan utilizing

"freedom of choice" is not an end in itself. As Judge Sobeloff has put it,

"Freedom of choice" is not a sacred talisman; it is only a means to a constitutionally required end-the abolition of the system of segregation and its effects. If the means prove effective, it is acceptable, but if it fails to undo segregation, other means must be used to achieve this end. The school officials have the continuing duty to take whatever action may be necessary to create a "unitary, nonracial system."

Although the general experience under "freedom of choice" to date has been such as to indicate its ineffectiveness as a tool of desegregation, there may well be instances in which it can serve as an effective device. Where it offers real promise of aiding a desegregation program to effectuate conversion of a stateimposed dual system to a unitary, nonracial system there might be no objection to allowing such a device to prove itself in operation. On the other hand, if there are reasonably available other ways, such for illustration as zoning, promising speedier and more effective conversion to a unitary, nonracial school system, "freedom of choice" must be held unacceptable.

ld. at 440-41 (footnote and citations omitted).

The Supreme Court itself has long approved desegregation plans that supplement mandatory reassignment provisions by including a "majority-to-minority" transfer provision, which allows pupils to transfer from a school where their race is a majority to one where their race is a minority. See Swann v. Charlotte-Mecklenburg Bd. of Educ., 402 U.S. 1, 26-27 (1971). Thus, the Court has already approved "choice" features in desegregation plans, but only where the choices are part of a mandatory reassignment plans and will contribute to achieving a more integrated result.

109. Green, 391 U.S. at 439. 
Thus, a court could order a "choice plus" remedy, allowing people to choose their schools but also insisting that the school board make certain changes in the opportunity set to try to induce integrative choices. ${ }^{110}$ This is one basis for requiring so-called "magnet schools," which, as their name suggests, aim to provide such improved educational quality that whites as well as blacks will be drawn to attend them. In theory at least, by offering enough incentives school boards could make integrative choices irresistible and thereby achieve the same outcome as a mandatory reassignment plan.

Indeed, using a choice system to promote integration has major advantages over a mandatory reassignment plan. Even though choices are actually being manipulated by incentives and other measures, ${ }^{111}$ people are not likely to feel the same coercion they experience when subject to mandatory reassignment. Where students feel instead that integration is their voluntary, consensual decision, and are promised desired educational improvements as part of the package, they are more likely to support integration and less likely to "flee."112 The problem of "white flight" is especially important in the situation where there is already a high concentration of minority students in a school system. Because of the Supreme Court's 1974 decision in Milliken $v$. Bradley (Milliken I), ${ }^{113}$ which disallowed metropolitan-wide busing in most instances, any plan seeking integration in this situation will have difficulties because of a shortage of white students. ${ }^{114}$ But coercive integration remedies can exacerbate these difficulties by stimulating additional "white flight." A choice-plus-incentives remedy might prevent this flight, ${ }^{115}$ and also reduce other burdens that mandatory assignment remedies can impose on a community and its citizens. ${ }^{116}$ Moreover, choice-plus-incentives remedies provide a convenient legal lever for requiring state and local governments to provide significant new

110. See, e.g., Liddell v. Missouri, 731 F.2d 1294, 1310-11 (8th Cir.) (citing cases), cert. denied, 105 S. Ct. 82 (1984); infra note 135-38 and accompanying text.

111. The point of the remedy is not to make choices "free," but to induce a result.

112. See, e.g., United States v. Board of Educ., 554 F. Supp. 912, 924-25 (N.D. 111. 1983) (citing Comprehensive Student Assignment Plan); Arthur v. Nyquist, 547 F. Supp. 468, 470 (W.D.N.Y. 1982), aff d, 712 F.2d 809 (2d Cir. 1983), cert. denied, 466 U.S. 936 (1984); J. Coons \& S. Sugarman, supra note 90 , at 115-16.

113. 418 U.S. 717 (1974).

114. But see infra notes $165-80$ and accompanying text (proposing form of interdistrict relief that would not offend Milliken $I$ ).

115. Indeed, "choice plus" systems may also be able to induce whites to come back into the public school system, thereby making even more integration possible. Blank, Dentler, Baltzell \& Chabotar, Survey of Magnet Schools: Analyzing a Model for Quality Integrated Education, Final Report of a National Study for U.S. Dep't of Educ., at 99 (Sept. 1983); see also Gewirtz, supra note 15, at 635-43 (discussing other harms of flight).

116. See D. Bell, supra note 4 , at $425-27$; J. Wilkinson, supra note 80 , at $171-77$ (noting that mandatory integration can create travel burdens, economic burdens, community divisiveness, and even interference with education). 
funding for educational improvements, which produce benefits quite apart from any integration they may induce. ${ }^{117}$

In practice, however, there are fundamental problems with this defense of choice. First, courts and researchers have reported again and again that, with some exceptions, voluntary techniques have generally had only limited success in producing integration, particularly in inducing whites to attend previously "black" schools. 118 Choice plans may produce less white flight, but they often fail to produce many integrative choices-and the net result can be much less integration than under a mandatory plan. Perhaps the only problem in these situations is that incentives are not made powerful enough to overcome individuals' reluctance to choose integrated settings; but since highly emotional feelings are involved here, both about one's children and about race, whites may flatly reject or undervalue any offered incentives and simply refuse to send their children to majority black schools as long as they have the choice. In addition, since a choice plan's effectiveness de-

117. See, e.g., Arthur v. Nyquist, 712 F.2d 809, 813 (2d Cir. 1983), cert. denied, 466 U.S. 936 (1984). Indeed, local school board defendants may themselves support the choice approach as a way of trying to extract additional funding from both local and state officials in the name of assisting with a required "desegregation" remedy. See infra notes 154-57 and accompanying text (discussing other legal theories for educational improvements remedy).

118. Green itself noted that "the general experience under "freedom of choice' to date has been such as to indicate its ineffectiveness as a tool of desegregation." 391 U.S. at 440 (footnote omitted). Since then, a variety of techniques based on choice have been proposed or tried, usually along with magnet schools, and generally have had only limited results. As Hochschild summarizes the data, "with a few exceptions, magnets have little effect on racial isolation unless they are part of a districtwide mandatory plan." J. Hochschild, supra note 55, at 71 (emphasis added). For some judicial views, see, e.g., Adams v. United States, 620 F.2d 1277, 1295 (8th Cir.) ("[v]oluntary techniques [with magnat schools] will not effectively desegregate the St. Louis school system"), cert. denied, 449 U.S. 826 (1980); Lee v. Marengo County Bd. of Educ., 588 F.2d 1134, 1136 (5th Cir.) ("freedom of choice . . . has not worked"), cert. denied, 444 U.S. 830 (1979); Morgan v. Kerrigan, 530 F.2d 401, 410 (1st Cir.) ("Like freedom of choice, the use of magnet schools to achieve voluntary desegregation has failed elsewhere," and "could not realistically sustain the burden of achieving desegregation" here.) (citing cases), cert. denied, 426 U.S. 935 (1976); Little Rock School Dist. v. Pulaski County Special School Dist., 597 F. Supp. 1220, 1225 (E.D. Ark. 1984) ("[D]esegregation plans based upon freedom of choice have proved to be total failures.").

Even the scholarly defenders of magnet schools as a desegregation device usually concede that magnets yield only partial and imperfect results (although in their view, often better results than the alternatives), see Rossell, Applied Social Science Research: What Does It Say About the Effectiveness of School Desegregation Plans?, $12 \mathrm{~J}$. Legal Stud. 69, 73 (1983) [hereinafter cited as Rossell, Applied Social Science Research]; Rossell, What Is Attractive About Magnet Schools?, 20 Urb. Educ. 7, 8 (1985) [hereinafter cited as Rossell, Magnet Schools], and will be more effective when part of a mandatory plan "including pairing, rezoning, two-way busing and mandatory assignment." Blank, Dentler, Baltzell \& Chabotar, supra note 115, at 219. Differing views, counterexamples, and supposed counterexamples are examined further below; but the point here is that the general experience suggests that we should be skeptical that choice plans, even with magnets, can desegregate a school system. 
pends on efforts by school officials to actively encourage integrative choices, ${ }^{119}$ it will fail if reluctant officials simply do not try very hard. Moreover, effectiveness is inseparable from the speed of success, and incentives such as magnet schools, which are absolutely necessary if a choice system is to have any chance of working, take considerable time to establish. Green said a school board's duty is to desegregate "now," and delay itself makes the remedy imperfect. ${ }^{120}$

In any event, even if it were possible to promptly achieve the required remedial results by providing powerful incentives for integrative choices, the incentives necessary to yield an effective remedy might prove too costly. The distinctive costs of a "choice plus" system include both the enormous expense of improving educational programs and creating magnet schools and also large expenses for transportation, which must be as individualized as the choices themselves (even requiring individual taxi service in some instances). ${ }^{121}$ At some point

119. See United States v. Wilcox County Bd. of Educ., 494 F.2d 575, 580 (5th Cir.), cert. denied, 419 U.S. 1031 (1974); Arthur v. Nyquist, 566 F. Supp. 511, 516-17 (W.D.N.Y. 1983); Blank, Dentler, Baltzell \& Chabotar, supra note 115, at 15, 110, 111.

120. Green v. County School Bd., 391 U.S. 430, 438-39 (1968); see Davis v. East Baton Rouge Parish School Bd., 721 F.2d 1425, 1437 (5th Cir. 1983). Choice systems may not be fully effective for another reason. Since the violation included the symbolic affront of the government's using its power to compel its citizens to segregate, an effective remedy arguably requires the government to counter the symbolic affront by a symmetrical compulsion that its citizens integrate. A choice remedy cannot do this since it leaves segregation to the decisions of individual citizens.

121. See J. Hochschild, supra note 55, at 76 (in start-up phase, St. Louis "spent roughly double the average per-pupil expenditure for regular students on its magnet program" and, in general, "[m]agnets cost about 27 percent more than nonmagnets for student transportation"); Blank, Dentler, Baltzell \& Chabotar, supra note 115 , at 15 ("average total cost per student in magnet schools was approximately $\$ 200$ more than nonmagnets"). A conservative estimate of the cost of Buffalo's magnet-based desegregation program was put at $\$ 18.15$ million for the $1982-83$ school year alone. See Arthur v. Nyquist, 712 F.2d 809, 815 (2d Cir. 1983) (also noting that "it is more costly to achieve desegregation through a plan that relies heavily on the voluntary preference of parents to send their children . . . to high quality schools than simply to pay for the busing of children to distant schools"), cert. denied, 466 U.S. 936 (1984). The district judge in the Chicago case determined that the costs of implementing the desegregation and compensatory education plan would be $\$ 171.6$ million in the first year, of which a substantial portion was designed to make the magnet program effective. See United States v. Board of Educ., 588 F. Supp. 132, 170, 221 (N.D. 1ll. 1984). San Jose spent $\$ 6.4$ million over five years on a maguet plan that produced little or no desegregation. Watson, Five Years, \$5 Million Fail to Integrate S.J. Schools, San Jose Mercury News, June 17, 1985, at 1A, col. 1. Officials of Prince George's County, Maryland, estimate that its newly-instituted magnet plan will cost $\$ 12$ million a year. See Vobejda, P.G. to Fund Magnet Schools with $\$ 9$ Million Surprise Surplus, Washington Post, Sept. 20 , 1985 , at C1, col. 1. In St. Louis, the city spent an estimated $\$ 1.1$ million simply for taxicab fares in its desegregation program during 1983, with daily fares ranging from $\$ 10-\$ 70$. Schwed, School Desegregation By Taxicab, U.P.1., St. Louis, Mo., Oct. 30, 1983.

A related cost of using a choice system that relies heavily on magnet schools is that it can "skim" both a class of pupils and financial resources into the more selective 
short of achieving a fully effective remedy, a practical cost limit to achievable integration may be reached. ${ }^{122}$

The truth is that all available integration remedies are likely to be imperfect to some degree. Judges have to compare plans and choose the best among the imperfect. Under current doctrine, a court's task is to decide which remedy will achieve "the greatest possible degree of actual desegregation, taking into account the practicalities of the situation." 123 A choice remedy is acceptable only if it "promises realistically"124 to meet that standard.

When comparing a choice plan and a mandatory integration plan under that standard, four aspects of the standard must be kept in mind. First, the measure of effectiveness is the net integration a plan producesits success in both achieving integration and preventing flight. ${ }^{125}$ Mandatory integration may provoke flight that undercuts the promised integration; choice plans may prevent some flight, yet not produce integrative choices. Second, courts must assess effectiveness over time, taking account both of immediate effects and less immediate ones: mandatory integration can rearrange a lot of pupil assignments immediately, but may continue to produce white flight for years; a choice plan may take longer to phase in, but may produce more stable integration after a while. ${ }^{126}$ Third, comparisons must be parallel. If a choice plan keeps whites in the system because of educational sweeteners or because a pledge is made that magnet schools will not have more than a fifty percent black student body, the comparison should be made to a mandatory plan where the schools are also sweetened and where some form of racial ceiling is used.

Finally, those proposing a choice remedy should have the burden of persuading the court that their particular plan will be as effective as a mandatory remedy. ${ }^{127}$ The rationale for this is not simply that

schools, with resulting educational harms and unfairness to those left behind. See, e.g., J. Hochschild, supra note 55, at 77-78.

122. See, e.g., Little Rock School Dist. v. Pulaski County Special School Dist. No. 1, 597 F. Supp. 1220, 1224 (E.D. Ark. 1984) (magnet/choice concept "not economically feasible at this time"); infra notes 140-42 and accompanying text (East Baton Rouge case).

123. Davis v. Board of School Comm'rs, 402 U.S. 33, 37 (1971).

124. Green, 391 U.S. at 439.

125. For a social scientist's formulation, see Rossell, Applied Social Science Research, supra note 118, at 94 . For elaboration of the legal relevance of white flight, see, e.g., Lee v. Anniston City School Sys., 737 F.2d 952, 957 n.3 (11 th Cir. 1984); Liddell v. Missouri, 731 F.2d 1294, 1314 (8th Cir.), cert. denied, 105 S. Ct. 82 (1984); Gewirtz, supra note 15 , at $628-65$.

126. While Green does say that desegregation plans must promise to work "now," it is just as important for a plan to work "later." A plan that takes time to build momentum may turn out to produce the "greatest actual desegregation" in the aggregatealthough obviously the court must take account of the way in which delay itself undercuts overall effectiveness.

127. The lower courts generally seem to be applying this burden of proof and this 
mandatory remedies are those traditionally used or that the limited experience with choice remedies is rather discouraging. As importantly, since a choice plan pursues integration indirectly, its ability actually to produce integration is inherently more speculative than a mandatory plan. Moreover, an argument that a choice plan will produce more integration than a mandatory plan is plausible only where white flight is likely, and that too is quite speculative. Courts cannot simply assume that flight will be a significant and irreversible problem in every school system; the likelihood and extent of flight depends upon the racial composition of the system, the particular design of the desegregation plan, and a range of setting-specific variables. ${ }^{128}$ In a system with a majority of whites, for example, those who propose an inherently speculative choice plan should have the burden of justifying both their fears about white flight and their optimism that people will actually choose integrated settings. Courts should be extremely cautious to conclude that the most effective way to promote remedial integration is some method other than the obvious one: directly ordering it.

While courts must be deeply skeptical about approving a choice remedy, there are enough difficulties with the more coercive remedies, and enough appeal to the possibility of creative noncoercive solutions, that the courts should be willing to give some kinds of choice remedies a chance-provided they are treated as an experiment and provided they contain specific features that make realistic the prospect of actually achieving the greatest possible degree of integration. The threshold requirement, of course, is that the plan actually commit the defendant to achieving an integrated result. To say that the plan must be treated as an experiment means that the court must also make clear that if the choice mechanisms fail to achieve that result, the court will impose mandatory measures in their place. ${ }^{129}$ This mandatory "back-up" gives plaintiffs a commitment they deserve and gives everyone in the community a necessary incentive to make the choice plan work. ${ }^{130}$ The "back-

substantive standard when evaluating choice proposals. See, e.g., Davis v. East Baton Rouge Parish School Bd., 721 F.2d 1425, 1437 (5th Cir. 1983); United States v. DeSoto Parish School Bd., 574 F.2d 804, 818 (5th Cir.), cert. denied, 439 U.S. 982 (1978); United States v. Wilcox County Bd. of Educ., 494 F.2d 575, 580 (5th Cir.), cert. denied, 419 U.S. 1031 (1974); Morgan v. Nucci, 602 F. Supp. 806, 809 (D. Mass. 1985).

128. See Gewirtz, supra note 15, at 629-30; Rossell, Applied Social Science Research, supra note 118 , at 87-93.

129. More general issues about a court's role when desegregation plans do not "work" are discussed infra notes 193-220 and accompanying text (termination question).

130. The importance of linking the choice plan to a mandatory back-up is emphasized by leading social scientists. See, e.g., J. Hochschild, supra note 55, at 71; G. Orfield, Toward a Strategy for Urban Integration: Lessons in School and Housing Policy from Twelve Cities 38 (1981); Hawley, Equity and Equality in Education: Characteristics of Effective Desegregated Schools, in Effective School Desegregation 297, 302 (W. Hawley ed. 1981); Blank, Dentler, Baltzell \& Chabotar, supra note 115, at 83, 219; Rossell, Magnet Schools, supra note 118, at 8, 17; Rossell, The Effectiveness of Alternate 
up" can take various forms, ranging from a general commitment by the court to impose a mandatory plan if the choice plan as a whole fails after a period of time, ${ }^{131}$ to a much more specific and individualized "back-up."

The Buffalo school desegregation remedy is a good example of the latter. Buffalo is one of the great success stories of the modern desegregation effort, and it is widely held up as a model of a system successfully integrated through a choice plan utilizing magnets. ${ }^{132}$ But this characterization is very misleading. The Buffalo desegregation remedy has relied on a broad variety of magnet schools from which people could choose, but the plan provides that children who do not choose and receive a magnet school will almost always be assigned to an integrated school outside of their neighborhood for nearly half of their grade-school years. This kind of "back-up" is so close to an individualized ultimatum that Buffalo's success story seems more attributable to compulsion than to voluntarism. Buffalo seems to have relaxed the compulsion just enough to avoid the resentments produced by a purely mandatory remedy, but less compulsion would probably have produced less net integration. If Buffalo is a model of how to make a "choice" plan work, part of the lesson is that it must be thoroughly intertwined with a mandatory program. ${ }^{133}$

In addition to providing for a mandatory back-up, no court should approve a choice plan which does not include other specific features that experience and research have shown are necessary to create a realistic prospect of producing integration. Plans that do not include such features would not "promise realistically" to "achieve the greatest degree of actual desegregation."134 These features include: Establishing magnet schools on a significant scale, with a credible explanation of

Desegregation Plans for Prince George's County, Maryland, at 31-32 (June 4, 1985) (attachment to Brief for Laurel Amici in Vaughns v. Board of Educ., No. 72-325-K (D. Md. Jan. 8, 1985)).

131. See, e.g., United States v. Texas Educ. Agency, 679 F.2d 1104, 1114 (5th Cir. 1982); Vaughns v. Board of Educ., No. 72-325-K (D. Md. June 30, 1985); Boyd v. Pointe Coupee Parish School Bd., 534 F. Supp. 555 (M.D. La. 1982); Smiley v. Blevins, 514 F. Supp. 1248, 1261 (S.D. Tex. 1981).

132. Winerip, School Integration in Buffalo is Hailed as a Model for U.S., N.Y. Times, May 13, 1985, at Al, col. 5.

133. See Arthur v. Nyquist, 473 F. Supp. 830, 849 (W.D.N.Y. 1979), and 514 F. Supp. 1133, 1137 (W.D.N.Y. 1981); Winerip, supra note 132; Christensen \& Eppler, School Desegregation in Buffalo: A Case Study of Arthur v. Nyquist (1985) (unpublished paper) (on file at the offices of the Columbia Law Review). These accounts suggest that the plan's success also resulted from the coming together of several other factors: the judge was skillful; the school board was cooperative; large amounts of funding were secured for a wide variety of magnet schools; the school system was majority white; the leadership repeatedly emphasized the "voluntary" elements of the plan and the public accepted that characterization in spite of the coercive back-ups; and the community was involved in the planning and implementation of the program.

134. See supra notes 123-24 and accompanying text. 
how these expensive items will be funded; locating magnets, ${ }^{135}$ staffing them with personnel, ${ }^{136}$ and designing their curricula in ways that promote integrative choices (for example, if a magnet is located in a majority black neighborhood, it should be staffed with a white principal and integrated faculty and include curricular offerings that are known to appeal to white parents); ${ }^{137}$ closing some schools in order to restrict segregative choices; and giving parents some advance assurance that racial balance in particular schools will be maintained. ${ }^{138}$ In addition, the evidence indicates that the more successful choice-plus-magnet plans have involved school officials who are enthusiastically committed to making the plan work-to selling the plan to the public and inducing family after family to make integrative choices. ${ }^{139}$ A court cannot order this indispensible salesmanship-a factor which should always make a judge hesitant to accept a choice plan-but the judge should surely reject a choice plan if he has a specific reason to doubt the school board's commitment to the plan.

No one should have any illusions that a plausible choice plan will be inexpensive. Costly magnet schools and other educational incentives are the centerpiece of the choice idea. It is the prospect of securing a better education that induces people to make integrative choices, and it is the promise that choice remedies provide a legal lever for securing more public money for education that attracts many people to the basic choice concept in the first place. Someone must foot the bill, however. Those who bear the costs of these expensive incentives may indeed view them as burdensome, and there may well be a limit on the financial costs that courts will impose on unconsenting parties in the name of making choice remedies effective. But it is hypocrisy to oppose mandatory remedies on the ground that choice remedies would be at

135. See Rossell, Magnet Schools, supra note 118, at 8-9. But cf. Blank, Dentler, Baltzell \& Chabotar, supra note 115 , at 220 (claiming no significant correlation between magnet location and successful desegregation).

136. See Rossell, Magnet Schools, supra note 118, at 13-14; Crain \& Mahard, Desegregation and Black Achievement: A Review of the Research, Law \& Contemp. Probs., Summer 1978, at 17, 47.

137. See Rossell, Magnet Schools, supra note 118, at 9-10.

138. On maintaining racial balance, see Rossell, Magnet Schools, supra note 118, at 19; Final Report on Desegregation of Prince George's County Public Schools, submitted to the Court on March 11, 1985, in Vaughns v. Board of Educ., No. 72-325-K (D. Md.); Arthur v. Nyquist, 566 F. Supp. 511, 519 (W.D.N.Y. 1983). Such "ceilings" can be controversial, whether used as part of a choice plan or a mandatory integration plan. See Gewirtz, supra note 15, at 659-65. Necessarily, they exclude some people based on race, and in school districts with a high percentage of minorities they assure the continuation of some one-race black schools. Where a school in a minority neighborhood is closed down in order to be reopened as a magnet, and a minority ceiling is then put in place, the overall effect is to assure that more minority children will have to attend schools outside of their neighborhood. These steps can be justified, if at all, only where they are necessary to produce stable integration.

139. See supra notes 119,133 . 
least as effective and then to oppose the expenditure of funds necessary for voluntary remedies to have even a chance of working.

In its first years in office, the Reagan Administration seemed to recognize the basic prerequisites of a permissible choice remedy. In the East Baton Rouge case, the Department of Justice conceded that a choice plan was legally acceptable only if it "worked" to achieve a "level of desegregation" that was "comparable" to that of a mandatory integration plan. 140 While the choice-plus-incentives plan that the Department proposed had significant flaws, it insisted on substantial funding of incentives by the school board and did seem to be a relatively promising means of achieving an integrated end.141 Moreover, when the school board rejected this plan because it was too expensive, the Administration supported a mandatory plan. ${ }^{142}$

But if the Administration was once committed to making choice work to produce integration, ${ }^{143}$ its attitude has clearly changed since then. On the legislative front, it has successfully sought to block funding for magnet schools-persuading Congress, for example, to eviscerate the Emergency School Aid Act, the main federal program that has helped to finance magnet schools in desegregation cases. ${ }^{144}$ Even

140. Brief of the United States at 5, Davis v. East Baton Rouge Parish School Bd., 721 F.2d 1425 (5th Cir. 1983); see supra notes 123-24 and accompanying text.

141. The Administration's plan provided for significant numbers of expensive magnet schools, whose location and character were specifically designed to promote integration, and it provided for the closing of schools that would impede the desegregation effort. Brief of the United States at 5-7, Davis. The Administration contrasted its plan to an earlier choice plan proposed by the school board, which it said lacked "sufficient supporting details to demonstrate its likelihood of success" (including details about funding), and failed to "utilize a variety of measures that could facilitate the magnets" usefulness as a desegregation device." Id. at 14-15. The Administration's plan, however, did not gnarantee any particular result, nor did it provide a mandatory back-up, two features that seem essential.

142. The Justice Department's choice-plus-incentives plan was proposed as a replacement for a mandatory plan already in place. 1d. at 4-5. After the school board balked at the expense of the Department's choice plan, Supplemental Submission of the United States at 4, Davis (filed Feb. 17, 1983), the Department supported the mandatory plan that the District Court had ordered. See Brief of the United States at 6-7 Davis.

143. In spite of occasional briefs like the one filed in the East Baton Rouge case, the leadership of the Civil Rights Division of the Justice Department may never have been committed to school integration. Even during his first year in office, Assistant Attorney General William Bradford Reynolds, Jr., stated: "We are concerned, quite frankly, much less with student relocation than we are with student education and our scliool desegregation plans will be drawn to reflect that predominant concern." Speech by William Bradford Reynolds, Jr., Before the Education Commission of the States (Sept. 27, 1981) (quoted in United States v. Board of Educ., 588 F. Supp. 132, 147 (N.D. Ill.), rev'd, 744 F.2d 1300 (7th Cir. 1984)).

144. In its final fiscal year (1981), the Emergency School Aid Act, Pub. L. No. 92318 , 86 Stat. 235 (1972), provided school districts with over $\$ 149$ million in financial assistance for magnet schools and other desegregation efforts. 130 Cong. Rec. S6680 (daily ed. June 6, 1984) (statement of Sen. Moynihan). In 1981, at the request of the Reagan Administration, this categorical grant program was subsumed in the Educational 
more significantly, on the litigation front the Administration has repeatedly endorsed choice remedies that cannot possibly be defended as a means to an integrated end. In Bakersfield, California, for examplea school district in which whites are the predominant racial group, and where mandatory integration seemed feasible-the Administration settled for a free choice plan that established only a handful of magnet schools, made no commitment to attain an integrated result, provided no mandatory back-up, and provided for an automatic declaration of unitariness after three years simply if the plan was implemented in good faith-regardless of whether the plan actually produced integration. ${ }^{145}$ The Justice Department has called the Bakersfield plan "a blueprint for desegregation in the future," 146 and has agreed to similar plans in Phoenix, Arizona; Lima, Ohio; and Lubbock, Texas. ${ }^{147}$ Even if choice can be defended in some instances as a plausible means to an integrated end, any pretense that this is the Reagan Administration's policy can no longer be sustained. ${ }^{148}$

Consolidation and Improvement Act of 1981, Subtitle D of the Omnibus Budget Reconciliation Act of 1981, Pub. L. No. 97-35, 95 Stat. 357 (codified in scattered sections of 20 U.S.C.). The result of this change to a block grant approach was a dramatic reduction in federal funds available for magnet schools. See Blank, Dentler, Baltzell \& Chabotar, supra note 115, at 226-27; 130 Cong. Rec. S6679 (daily ed. June 6, I984) (statement of Sen. Moynihan). In June, I984, Congress restored some funding for magnet school assistance. See Education for Economic Security Act Amendments, Pub. L. No. 98-377, 98 Stat. 1299-1302 (codified at 20 U.S.C. §§ 3901-4074). While President Reagan signed the total legislative package, he did so reluctantly. See Statement on Signing H.R. 310 into Law, 20 Weekly Comp. Pres. Doc. 1120, 1121 (Aug. 11, 1984) (bill contains "objectionable provisions" that are "unrelated to improving science and mathematics instruction"). Tbe Office of Management and Budget then promptly targeted the program for rescission in its 1986 budget, and the Education Department delayed for months the issuance of the relevant governing regulations. The delay resulted in no funds reaching school districts for the 1984-85 academic year. See Playing With Magnets, N.Y. Times, Apr. 23, 1985, at A26, col. I (editorial); see infra note I48.

145. The plan itself is unpublished, but is on file at the offices of the Columbia Law Review. See also infra notes 214-16 and accompanying text (discussing remedies).

146. Pear, U.S. Shifts Tactics on Desegregation of Lower Schools, N.Y. Times, Jan. 26, 1984, at Al, col. I (quoting Assistant Attorney General William Bradford Reynolds, Jr.). Since the Department views the plan as a "blueprint," its weak provisions cannot be excused because they are part of a consent decree settlement.

147. These unpublished plans are on file at the offices of the Columbia Law Review.

148. Chicago's school desegregation case provides a particularly dramatic example of how the Administration undercut a trial court which had placed its faith in a choice plan. In January 1983, District Judge Milton Shadur approved a proposed settlement between the United States and the Chicago Board of Education that sought to desegregate the Chicago school system exclusively by voluntary means, including magnet schools. See United States v. Board of Educ., 554 F. Supp. 912 (N.D. Ill. 1983). The Reagan Administration hailed the plan as an example of its new approach. The plan incorporated a consent decree in which each party agreed " 'to make every good faith effort to find and provide every available form of financial resources adequate for the implementation of the desegregation plan,' "567 F. Supp. 272, 285 (N.D. IIl. 1983). As could have been predicted, the financial cost of using educational incentives to desegre- 


\section{Choice as the Best Means to Achieve Multiple Corrective Goals}

A final defense of choice remedies may be the most novel and may raise the most interesting issues of remedial theory. A choice-plus-educational-improvements remedy, it might be said, is best in achieving a range of corrective goals not limited to integration. While this defense can take many forms, its basic thrust seems to have united some whites who have traditionally opposed mandatory integration efforts and some blacks who have backed off from the integration ideal as its achievement has proven more difficult. Let me first try to construct a version of the basic argument, ${ }^{149}$ and then state my problems with it.

A remedy for de jure school segregation, these choice defenders might affirm, properly seeks to eliminate educational deficiencies caused by the violation as well as eliminate segregated attendance pat-

gate a system like Chicago's proved to be enormous. The district court estimated that the desegregation plan, including both compensatory education and pupil assignment features, would cost $\$ 171.6$ million annually. 588 F. Supp. 132, 170 (N.D. Ill. 1984). Faced with the reality of what their new choice approach would cost if it was to have any chance of being effective, Administration officials boldly tried to renounce their financial obligations, "violat[ing] the letter as well as the spirit" of the agreement that the United States would provide an "adequate" amount of available financial resources. $621 \mathrm{~F}$. Supp. 1296, 1304 (N.D. Ill. 1985); see also Mirga, San Jose Desegregation Plan Ap. proved, Educ. Week, Jan. 8, 1986, at 8, col. 3 (ordering expenditures by United States) (quoting a recent unpublished opinion by the trial judge). See United States v. Board of Educ., 744 F.2d 1300, 1301-04 (7th Cir. 1984) (summarizing the litigation through 1984).

When Congress first passed a specific measure to help fund the Chicago plan, President Reagan vetoed the bill, arguing that the district court had exceeded its proper authority. See President's Message to the House of Representatives Returning H.J. Res. 538 Without Approval, 19 Weckly Comp. Pres. Doc. 1134 (Aug. 13, 1983); Devins \& Stedman, New Federalism in Education: The Meaning of the Chicago School Desegregation Cases, 59 Notre Dame Law. 1243 (1984) (summarizing more recent congressional and presidential actions). The Chicago School Board has expressed doubt about whether it can continue to meet the plan's funding needs without greater help from the federal government. See Taylor, Desegregation Cost Raises Board Dispute, Chicago Tribune, May 23, 1985, $\S 2$, at 1 , col. 5 . While this case is obviously unusual in that the United States as plaintiff had agreed to help finance a remedy for the defendant's violation, the case reinforces a fundamental point: choice plans can be sabotaged by problems in securing adequate funding, and trial judges should not approve them where credible sources of funding are not specified.

149. Elements of this argument appear in such works as D. Bell, supra note 4, at 424-31; Bell, Civil Rights Commitment and the Challenge of Changing Conditions in Urban School Cases, in Race and Schooling in the City 194 (A. Yarmolinsky, L. Liebman \& C. Schelling eds. 1981) [hereinafter cited as Yarmolinsky Collection]; Coleman, supra note 4, at 14-15, 48-49; Jackson, Urban School Desegregation from a Black Perspective, in Yarmolinsky Collection, supra, at 204; Congress of Racial Equality, A Proposal for Community School Districts, in N. Mills, The Great School Bus Controversy 311 (1973). The current Administration sometimes echoes aspects of this argument, but without the commitment to substantially enhanced funding of black schools. See supra note 143. The argument seems to be implicit in a handful of lower court cases where educational remedies were ordered in lieu of otherwise achievable integration. See, c.g., Tasby v. Wright, 771 F.2d 849 (5th Cir. 1985). 
terns and racially identified schools. Mandatory integration is simply not the best remedy to achieve these various corrective goals. We have already seen some of the problems mandatory integration orders have had in actually producing stable integration in some instances. ${ }^{150}$ In addition, the educational gains to minority students from integration have not been clearly established. ${ }^{151}$ Black students, moreover, often face insensitivity and racism in integrated settings. Thus, the better remedial approach is to improve educational resources within traditionally all-black schools and then leave the decision about which school setting is best to the choice of each individual family. The enhancement of the educational quality of all-black schools may counteract various effects of a long regime of school segregation: it might contribute to the self-esteem of minority children, improve their education, improve all-black neighborhoods, and give greater prominence to AfroAmerican culture. A choice-plus-educational-improvements remedy would be imperfect, of course. For example, it probably would not eliminate the racial identifiability of the schools or counteract all the tainting factors that shape choices. Yet, when the full range of goals is considered, a choice remedy with educational improvements would often be more effective than mandatory integration, which would have even more imperfections. Add to this the fact that integration imposes many costs that a choice plan would avoid-including interference with the preferences of many students of both races-and the comparative advantage of choice is even clearer.

It must be noted immediately that this defense of choice is actually a defense of a choice-plus-educational-improvements remedy, not choice itself. Educational improvements play a very different role in this defense of choice than in the prior one, where such improvements were discussed as a means of producing integration, the only explicit remedial goal. Here, educational improvements are relevant in their own right, because they also promote a separate remedial goal. The critical step in this final defense of choice is a shift in corrective goals from the conventional focus on "desegregation"-eliminating segregated attendance patterns and racially identified schools-to educational improvement as an additional or even exclusive remedial goal.

Curiously, there is considerable confusion in the literature about the basic legal status of this goal. Some have suggested that since the "violation" in Brown is generally understood to have been the de jure

150. See supra notes $113-16$ and accompanying text.

151. See N. St. John, supra note 4, at 136 . But see Crain \& Mahard, supra note 136 , at 695-96 (summarizing studies showing educational gains); infra note 160 . lndeed, the effectiveness of a mandatory integration remedy is limited by some of the very factors noted earlier in explaining why blacks' choices under a freedom of choice plan might be tainted by discrimination. For example, it was suggested that the prospect of white harassment in a newly integrated setting might deter blacks from choosing integration if they were given the choice, but it is also true that where this harassment is a reality it limits the effectiveness of an integration remedy. 
segregation of pupils, the only proper "remedial" goal is elimination of the segregation, not direct improvement of educational quality. ${ }^{152}$ Others, seeming to grant the weight of this prior suggestion, have criticized Brown itself, arguing that the "right" there should be redefined as a right to an effective education rather than a right to be free of de jure segregation. ${ }^{153}$ But a remedial goal of improving black education is fully consistent with Brown and subsequent legal history. Corrective principles require elimination of all "condition[s] that . . . flow from [the] violation."154 After longstanding de jure segregation, those conditions are likely to include educational harms. Although the courts have overwhelmingly focused on the corrective goals of eliminating segregated attendance patterns and racial identifiability, the elimination of other ongoing effects of de jure segregation, including educational harms, is also an appropriate corrective goal; this, in fact, shows the great power of corrective ideas. The Supreme Court has recognized as much: as part of the remedy for de jure segregation in Milliken v. Bradley (Milliken II), ${ }^{155}$ the Court approved certain compensatory educational requirements in order to overcome educational deficiencies resulting from unlawful segregation. ${ }^{156}$ The amount and type of educational improvements ordered under this rationale are shaped, of course, by the goal they are supposed to serve-they must provide compensatory education, not simply at-large improvements of educational quality or incentives for integrative choices ${ }^{157}$ - but corrective

152. See, e.g., Jones, Correspondence, 86 Yale L.J. 378 (1976).

153. See, e.g., Bell, The Burdens of Brown on Blacks: History-Based Observations on a Landmark Decision, 7 N.C. Cent. L.J. 25, 36-38 (1975); Carter, Reexamining Brown Twenty-Five Years Later: Looking Backward Into the Future, 14 Harv. C.R.-C.L. L. Rev. 615,623 (1979).

154. Milliken v. Bradley (Milliken II), 433 U.S. 267, 282 (1977).

155. 433 U.S. 267 (1977).

156. Id. Examples of lower court cases furnishing extensive "Milliken II" relief are Liddell v. Missouri, 731 F.2d 1294 (8th Cir.), cert. denied, 105 S. Ct. 82 (1984); Kelly v. Metropolitan County Bd. of Educ., 687 F.2d 814, 816-17 (6th Cir. 1982), cert. denied, 459 U.S. 1183 (1983); Evans v. Buchanan, 582 F.2d 750, 767-74 (3d Cir. 1978), cert. denied, 446 U.S. 923 (1980); United States v. Board of Educ., 588 F. Supp. 132 (N.D. 111. 1984), rev'd on other grounds, 744 F.2d 1300 (7th Cir. 1984); Tasby v. Wright, 520 F. Supp. 683, 741-42 (N.D. Tex. 1981), affd in part, rev'd in part, 713 F.2d 90 (5th Cir. 1983).

157. Where the goal is to induce integrative choices, the corrective conception permits whatever type and amount of educational enhancement is necessary to induce those choices. If the goal is compensatory education, corrective principles permit whatever type and amount of educational enhancement is necessary to eliminate educational harms caused by de jure segregation. But neither corrective theory permits a court to order educational quality improvements simply because that seems like a good policy. This has required courts to draw a line between new funding needed to "aid the success of the overall desegregation effort" (permissible to order) and new funding simply to "upgrad[e] an educational system in ways only remotely related to desegregation" (impermissible). Arthur v. Nyquist, 712 F.2d 809, 813 (2d Cir. 1983), cert. denied, 446 U.S. 936 (1984); see Liddell v. Missouri, 731 F.2d 1294, 1313-17 (8th Cir.), cert. denied, 105 S. Ct. 82 (1984). 
principles comfortably generate significant "educational" relief.

None of this, however, suggests the appropriateness of replacing the integration goal with the goal of improving educational quality in schools that remain racially identified and racially segregated. There are situations, of course, where the high minority concentration in a school system may make systemwide integration unachievable, and in these instances any compensatory educational relief will necessarily have to be provided in schools that remain segregated. ${ }^{158}$ But where integration is achievable, it must remain a remedial goal, even if compensatory education is also a goal. The question is whether a choiceplus-educational-improvements remedy can be justified as the most appropriate means of achieving these multiple goals.

To me, this seems unlikely. Some form of integration-plus-educational-improvements plan is likely to be the more effective strategy for achieving a range of remedial goals. As elaborated in the last section, it is doubtful that choice-plus-educational-incentives is better than some degree of mandatory integration in achieving the integration goal itself. In any case, the type of choice mechanism that might produce as much integration as a mandatory remedy is one where educational improvements are deliberately and aggressively designed to maximize integrative choices, not the type of choice option defended here.

A remedy that does not achieve attainable integration might nevertheless be justified if requiring integration would interfere with achieving other remedial goals such as improving education. This, however, seems doubtful. ${ }^{159}$ To be sure, some individual black students may well receive a better education in all-black schools than in integrated

158. In such situations, it is arguable that educational relief beyond what is necessary to compensate for past segregation is appropriate since segregation will be continuing in the future.

159. Until recently, I suspect, it was widely believed that all plausible remedial goals were achievable through the single strategy of mandatory integration. We now know that this may not be so. A range of different goals may require a range of different remedial strategies; for example, dismantling racially-identified schools may require integration, and overcoming educational deficiencies may require compensatory education programs. If there were a conflict among these strategies, that would simply begin a consideration of which goals and strategies to pursue.

If, for example, mandatory integration conflicted with improving black educational quality, one would have to be sacrificed to some extent. I initially thought that a proper view of corrective principles required that priority be given to a remedy that sought to eliminate the unlawful segregation that might produce educational problems, rather than a remedy that addresses educational problems that might exist within a racially separate setting that was itself preserved. See Gewirtz, supra note 15 , at 665 . But I no longer think that the corrective conception by itself requires such an a priori ranking. Educational effects that are attributable to the defendant's longstanding mandatory segregation stand on the same level as attendance pattern effects. If strategies to reduce one kind of effect conflict with strategies to reduce the other, then the remedy provider must choose which goals (and perhaps which victims) are more important- that is, choose among different concepts of remedial "effectiveness"- and must make the appropriate tradeoffs and compromises. Id. at 594-95. In doing so, the remedy provider 
settings, and therefore their decisions to decline integration, if given the choice, would be educationally superior. The available social science evidence, however, does not establish that this generalization is widely applicable to black children (there is debate about whether integrated education improves blacks' educational performance, but little suggestion that it hurts that performance). ${ }^{160}$ Compensatory educational improvements can surely be ordered as part of mandatory integration plans as well as choice plans. Moreover, while there may be some benefits to the black community from controlling all-black public schools in black neighborhoods, experience continues to teach both that an integrated education best prepares people for a racially diverse world and that "green follows white" (that is, in a society where whites remain the majority, the presence of whites in an institution protects that institution against racially unequal distribution of resources). ${ }^{161}$ In short, no actual conflict seems to exist between the strategy of ending segregated attendance patterns through mandatory integration and the achievement of other remedial goals.

Some, I suspect, do see a political conflict between the various goals. ${ }^{162}$ In particular, some blacks may have concluded that white decisionmakers will be willing to provide more in the way of educational improvements if blacks abandon the push for integration. But only in this most starkly political sense can it be said that integration conflicts with the achievement of other remedial goals for the plaintiff class-and a court's obligation is to defy these predictions.

This is not to deny that integration remedies have imperfections and may impose some costs on blacks and whites alike. These cannot be ignored by a court considering the adoption of an equitable remedy. ${ }^{163}$ But to avoid the distortions of taint and to vindicate individual

would have to invoke criteria that go beyond basic corrective principles themselves. The integration goal might not be sacrificed-but it might.

160. See, e.g., School Desegregation: Hearings before the Subcomm. on Civil and Constitutional Rights of the House Comm. on the Judiciary, 97th Cong., 1st Sess. 159 (1981) (statement of Gary Orfield); J. Hochschild, supra note 55, at 178-79; Crain \& Mahard, supra note 136, at 22-24; Epps, The Impact of School Desegregation on the Self-Evaluation and Achievement Orientation of Minority Children, Law \& Contemp. Probs., Summer 1978, at 57, 64, 71; Orfield, School Segregation and Residential Segregation: A Social Science Statement, in School Desegregation: Past, Present, and Future 231, 242 (W. Stephan \& J. Feagin eds. 1980). But see N. St. John, supra note 4, at 136 (citing studies that show negative effects on self-esteem).

161. See, e.g., J. Hochschild, supra note 55, at 172; Hawley, supra note 130, at 305. Hochschild's book sensitively explores alternatives to a school integration strategy, including a strategy of black control of black schools. In the end, she appears to rest her justification for an integration strategy on a version of these final arguments (albeit not put in specifically corrective terms): improved race relations require inter-racial contact, and "green follows white." Siguificantly, Hochschild does not preclude choice remedies as a means to that integrated end. J. Hochschild, supra note 55, at 70-79.

162. See, e.g., Bell, Brown and the Interest-Convergence Dilemma, in Shades of Brown, New Perspectives on School Desegregation 91 (D. Bell ed. 1980).

163. See Gewirtz, supra note 15, at 604-05, 648-49, 651, 655-56. 
remedial rights, the imperfections and cost-benefit assessment must be faced by the court in terms of the plaintiff class as a whole and the school system as a whole, not by the poor proxy of individual choice. In those terms, the claims for choice do not seem sustainable. A remedy of integration-plus-educational-improvements may have problems, but a choice-plus-educational-improvements remedy generally have even greater limitations. ${ }^{164}$

164. The recognition of the diversity of remedial goals and the likely imperfection of all strategies, however, suggests that some changes in context may change the acceptable role of choice. The problem of desegregating colleges and universities within previously segregated systems of higher education illustrates the point. In devising remedies for de jure segregation that produced a system of separate public colleges for whites and blacks in many states, courts and executive departments have generally used approaches that allow students freedom to choose the college they will attend. Unlike desegregation of elementary and secondary school systems, higher education remedies do not assign students to particular colleges in order to produce integration. In general, remedies have been approved even where the choice system seems likely to preserve racially concentrated attendance patterns, particularly at the traditionally black colleges. See, e.g., Adams v. Richardson, 480 F.2d 1159 (D.C. Cir. 1973); Alabama State Teachers Ass'n v. Alabama Pub. School \& College Auth., 289 F. Supp. 784 (M.D. Ala. 1968), affd, 393 U.S. 400 (1969); Revised Criteria Specifying the Ingredients of Acceptable Plans to Desegregate State Systems of Public Higher Education, 43 Fed. Reg. 6658-64 (1978) [hereinafter cited as HEW Criteria]; D. Bell, supra note 4, at 457-70; Dimond, supra note 71 , at $48-57$. While it has been suggested that this remedial pattern is simply a political sellout to white interests seeking to prevent integration, or (perhaps at the same time) a sellout to black educators at the traditional black colleges seeking to protect their status, see Clark, Separate Is Still Unequal, 215 Current 14, 15 (1979), and while I have many reservations about current higher education remedies myself, there is a way to understand the evolution of the law in terms of the corrective principles set out earlier.

In brief, the prevailing approach might well promote remedial effectiveness and reduce costs to a greater extent than the alternatives. First, in the context of colleges and universities, there is greater justification for preserving choice than in the context of elementary and secondary education. Colleges usually have distinctive programs and characteristics, and choice is traditionally used as the method of matching students to an appropriate college. The students themselves are older, may be freer of tainting attitudes, often make the choice for themselves, and view the decision as pivotal in their own developing self-identity. Second, even though a remedy that preserved the essential character of black colleges would not serve the goal of eliminating racially-identified institutions, it might well serve other important remedial functions in ways that analogous measures involving elementary and secondary schools would not-for example, providing space for disadvantaged black students who might not otherwise be admitted to college at all, contributing to the development of black cultural and intellectual life, and, argnably, providing a more effective educational setting for many of the black students who attend black colleges. (Of course, it might be thought that the employment prospects and life chances of students attending black colleges are harmed because of their relative isolation from white-majority institutions and because the broader public may continue to view racially identified black colleges as inferior schools.) Third, and the reverse side of the prior point, a mandatory integration remedy (or one that consolidated institutions so that none had a racial identity) would impose costs: it would probably reduce the overall number of places within the higher education system where blacks could gain admission, would destroy the character of black institutions that have achieved distinction even under conditions of adversity, and might be less effective educationally for some students. The inappropriateness of eliminating racially identified 


\section{E. Choice as an Interdistrict Remedy}

There is one possible use of a choice remedy that has not yet been adequately recognized by the courts or commentators, but which seems to have great potential-the possibility of requiring implementation of an interdistrict choice system as part of the remedy for an intradistrict violation. We have seen how the contemporary desegregation effort has been tremendously hampered by the fact that many urban school districts still suffering the effects of de jure segregation are now predominantly black. In the wake of the Supreme Court's 1974 decision in Milliken $v$. Bradley (Milliken I), ${ }^{165}$ which generally barred the use of interdistrict busing for an intradistrict violation, remedies have generally been limited to the geographic boundaries of a single district. As a result, achieving a meaningful degree of interracial contact is impossible in many city school systems, and the desegregation effort there is ending in failure.

My proposal is this: To dismantle racially identified city schools and promote integration, courts should consider ordering desegregation plans that (1) allow students in the city district to transfer to schools in surrounding suburban districts and suburban students to transfer to city schools, and (2) require city and state violators to pay the costs of fiscal incentives to encourage these voluntary integrative transfers, including transportation costs, tuition costs in the suburban schools, and

universities may seem all the greater if one believes that colleges with a racial character are likely to reemerge after a remedy period is over and choice is reinstituted.

Consistent with this analysis, then, one could probably justify a higher education remedy that preserved choice but (1) tried to integrate the traditionally white colleges by manipulating the background conditions and incentives (for example, the location of particular programs or the provision of scholarships); (2) tried to reduce some of the tainting features that might greatly distort choices; and (3) sought to preserve the basic character of traditional black colleges at least temporarily, while improving resources within them. This is essentially what the courts and agencies have done. E.g., United States v. Louisiana, 527 F. Supp. 509 (E.D. La. 1981) (consent decree); Artis v. Board of Regents, No. CV479-251 (S.D. Ga. Feb. 2, 1981); HEW Criteria, supra, at 6661-62; see Dimond, supra note 71, at 48-57. Viewed in the best light, these remedial rules initiate a process of self-reflection within the individuals who are choosing their educational futures, encouraging them to reassess choices and to consider surmounting the tainting constraints that may be channelling them to colleges traditionally for students of their race. The remedies provide encouragement and incentives for integrative choices, as they must if remedial rights to a desegregated education are to be even partially actualized and if the grosser tainting elements are to be muted; but they do not mandate integration. They accommodate the corrective function and distinctive cultural role of traditionally black colleges if enough blacks truly prefer them after being credibly invited to choose something else. They minimize a remedial bias towards permanently integrative antipluralist solutions. Too little, in my judgment, has been required under most of these remedies to secure integrative outcomes and to untaint choices; but allowing an imperfect choice system as the method of matching student to school seems more easily defensible in this context than in the realm of elementary and secondary schools.

165. 418 U.S. 717 (1974). 
the full cost of magnet schools in the city schools. Such a plan would create a real possibility for black students in the central cities to secure an integrated education and might even provide incentives for enough transfers by suburban students so that the racial identity of city schools could be reduced.

Although it might at first appear that the Milliken $I$ decision is an insuperable legal obstacle to such a proposal, it is not. Milliken I is not a general per se bar to "interdistrict remedies" for "intradistrict violations." In Milliken I, the lower courts had found the city of Detroit and the state of Michigan guilty of intentional school segregation in Detroit. Because Detroit's school system was predominantly black at the time of trial, the lower courts ordered that Detroit and the surrounding suburban school districts consolidate operations and devise a mandatory busing plan for the entire metropolitan area. ${ }^{166}$ By a five to four vote, the Supreme Court reversed, holding that this inclusion of suburban districts in the remedy for the violation within Detroit, absent an "interdistrict violation," was an inappropriate interference with the suburbs' "local autonomy."167

Two years after Milliken $I$, in Hills v. Gautreaux, ${ }^{168}$ the Supreme Court explicitly stated: "Nothing in the Milliken decision suggests a per se rule that federal courts lack authority to order parties found to have violated the Constitution to undertake remedial efforts beyond the municipal boundaries of the city where the violation occurred."169 In fact, the Supreme Court in Gautreaux approved a metropolitan-wide remedy for housing segregation within Chicago, including the placement of public housing within the Chicago suburbs, concluding that this would not improperly interfere with the suburbs' local autonomy. ${ }^{170}$ Thus, while Milliken I does generally bar a certain kind of interdistrict remedy-an interdistrict mandatory busing plan-it need not bar other forms of interdistrict relief.

Whether an interdistrict transfer plan is permissible turns on the answers to two questions. First, will an interdistrict transfer plan further the corrective goal of eliminating effects of the violation? Second, would it nevertheless interfere improperly with the suburbs" "local autonomy"? For urban centers like Detroit, the answer to the first question seems to be yes. The effects of the violation within Detroit-such as the racial identity of the schools and the segregated attendance pattern-cannot be completely eliminated by limiting the remedy to De-

166. The lower courts reasoned that a traditional busing remedy limited to the Detroit system would still leave the Detroit schools racially identified and would make the problem even worse by stimulating white flight. See Bradley v. Milliken, 484 F.2d 215, 244-45, 249-50 (6th Cir. 1973).

167. Milliken $I, 418$ U.S. at 741-42.

168. 425 U.S. 284 (1976).

169. Id. at 298.

170. Id. at $300-06$. 
troit; interdistrict relief would help, even the imperfect relief provided by an interdistrict choice plan. Milliken I's rejection of interdistrict relief does not rest on a disagreement with this assessment. The point of Milliken I "is not that a within-Detroit remedy would fully eliminate effects of the violation, but rather that an interdistrict remedy that would clearly have been more effective was thought to impose costs that were too great"-that is, it would excessively interfere with local autonomy. ${ }^{171}$

Would an interdistrict choice plan do that also? I think not. ${ }^{172}$ As Gautreaux establishes, the mere fact that the suburbs are involved in the remedy does not mean that their "autonomy" is infringed upon. Milliken I reflects the Court's concern that a mandatory interdistrict integration decree would require the suburban districts to fundamentally "restructure" their operations and endure significant financial burdens. ${ }^{173}$ Realistically, Milliken I reflects the Court's unease with coercive and disruptive busing-and-consolidation remedies. But an interdistrict transfer provision, which relies on the voluntary choices of individuals, has an altogether different character.

Even though it requires suburban districts to let their own residents attend schools elsewhere and to accept some transfers from the city school system, an interdistrict transfer provision neither requires the suburbs to restructure their school districts nor requires suburban residents to leave their neighborhood schools. ${ }^{174}$ Requiring the suburbs to accept some city transfer students seems no more intrusive than requiring the suburbs in Gautreaux to accept new integrated housing projects; ${ }^{175}$ permitting some suburban students to opt out seems much

171. Gewirtz, supra note 15, at 647 ; see Liddell v. Missouri, 731 F.2d 1294, 1306-08 (8th Cir.), cert. denied, 105 S. Ct. 82 (1984).

172. The argument 1 am making here in support of an interdistrict transfer remedy does not at all depend on Milliken I's exception for cases where an "interdistrict violation" is shown. Milliken I, 418 U.S. at 745. This exception has been invoked by a few lower courts that have been able to find an interdistrict violation. See, e.g., Hoots v. Pennsylvania, 672 F.2d 1107, 1120 (3d Cir.), cert. denied, 459 U.S. 824 (1982); Morrilton School Dist. No. 32 v. United States, 606 F.2d 222, 223 (8th Cir. 1979), cert. denied, 444 U.S. 1071 (1980); United States v. Missouri, 515 F.2d 1365, 1370 (8th Cir. 1975); Little Rock School Dist. v. Pulaski County Special School Dist., 597 F. Supp. 1220, 1225 (E.D. Ark. 1984); United States v. Board of School Comm'rs, 419 F. Supp. 180, 183-86 (S.D. Ind. 1975), aff', 541 F.2d 1211 (7th Cir. 1976), vacated sub nom. Metropolitan School Dist. v. Buckley, 429 U.S. 1068 (1977); Evans v. Buchanan, 393 F. Supp. 428, 432 (D. Del.), affd mem., 423 U.S. 963 (1975). My argument here is that even where there has only been a violation within a single district, interdistrict relief is appropriate where it does not infringe on the suburbs' local autonomy.

173. Hills v. Gautreaux, 425 U.S. 284, 305-06 (1976) ("[i]n contrast to the desegregation order in [Milliken], a metropolitan area relief order [in this case] would not consolidate or in any way restructure local governmental units").

174. While the interdistrict transfer plan proposed here would involve transfers both to and from the suburban districts, magnet schools would be ordered only in the city school district, further minimizing interference with the suburban system.

175. Like the remedy in Gautreaux, an interdistrict transfer plan "would not consoli- 
less intrusive. Moreover, if an interdistrict transfer provision had been ordered in Milliken I itself, where the state was a proven violator, the suburbs would not have been saddled with any new financial burdens. In such cases, which form the core of my proposal, ${ }^{176}$ the state can be required to share the financial costs of the interdistrict plan ${ }^{177}$-including the cost of tuition and transportation for those city children who choose to go to the suburban schools and the cost of magnets designed to induce suburban students to transfer to the city. In short, ordering an interdistrict transfer plan simply does not infringe on the interests of local autonomy that were Milliken I's concern. The very individualistic and nonsystemic features of a choice mechanism which make it somewhat troublesome in terms of vindicating victims' rights make it untroublesome as a threat to the "local autonomy" values identified in Milliken I.

No court has yet clearly affirmed the power to require an interdistrict transfer remedy for an intradistrict violation. In the St. Louis desegregation case, however, an en banc Eighth Circuit court recently approved a consent decree containing an interdistrict transfer provision. ${ }^{178}$ This case is legally significant. ${ }^{179}$ Even though court approval

date or in any way restructure local governmental units." Gautreaux, 425 U.S. at 305-06. The Gautreaux Court also noted that the suburban housing authorities retained rights to reject programs that were inconsistent with their approved housing plans and zoning rules, id. at 305 , just as suburban school authorities under my proposal would retain the right to reject students who did not meet their nondiscriminatory school entrance requirements or when transfer requests exceeded some reasonable number.

176. Should the state not be a proven violator, ordering interdistrict transfers would be harder to justify since the state would not be available to help absorb financial costs. The standards for holding the state liable are not my concern here, nor were they the Supreme Court's concern in Milliken I. See 418 U.S. at 748. It is worth noting, though, that some courts have recognized that a city school board is merely an agent of the state, and have indicated that the finding of a city's constitutional violation is sufficient to hold the state liable and subject to injunctive relief. See, e.g., San Francisco NAACP v. San Francisco Unified School Dist., 484 F. Supp. 657, 667-68 (N.D. Cal. 1979); Hart v. Community School Bd., 383 F. Supp. 699, 748-49 (E.D.N.Y. 1974), affd, 512 F.2d 37 (2d Cir. 1975).

177. There is also no doubt that the state (like HUD in Gautreaux) has the authority to take corrective steps throughout the state, in both city and suburb.

178. Liddell v. Missouri, 731 F.2d 1294 (8th Cir.), cert. denied, 105 S. Ct. 82 (1984). In addition, other judges have commented generally on the advantages of interdistrict transfer arrangements as something states and suburbs might undertake voluntarily. See, e.g., Columbus Bd. of Educ. v. Penick, 443 U.S. 449, 488 (1979) (Powell, J., dissenting); Little Rock School Dist. v. Pulaski County Special School Dist. No. 1, 778 F.2d 404, 436 (8th Cir. 1985) Ross v. Houston Indep. School Dist., 699 F.2d 218, 222-24 (5th Cir. 1983); Berry v. School Dist., 698 F.2d 813, 819-20 (6th Cir. 1983).

179. It is also significant in practice. The litigation has made considerable desegregation possible in the St. Louis metropolitan area. About 7,000 black students have transferred from St. Louis schools to suburban schools. (That number equals about one-fourth of the students who were attending all-black schools in St. Louis.) In addition, about 540 white suburban students have transferred to St. Louis schools. Conversation with David Tatel, Counsel to the Board of Education of the City of St. Louis (Apr. 
of a consent decree often tells us little about what a court may require, the court here explained its approval in ways that support my broader argument. ${ }^{180}$ Courts should now take the next step and be willing to order an interdistrict transfer plan even where the suburbs object. For judges who share the concerns expressed in Milliken I, but who also are deeply troubled by the continuing legacy of state-created racial isolation in so many urban schools, this approach can provide an attractive alternative. While not as forceful as a mandatory interdistrict remedy would be, it is virtually the only interdistrict approach still available under current doctrine. It may be the most promising approach available to overcome the remedial stalemate that now allows so much segregation to endure.

\section{Boundaries of the Corrective Conception}

Because individual choice is such a fundamental value in American life, my argument that the corrective conception requires us to be extremely distrustful of choice demonstrates how extraordinarily powerful the corrective aspiration can be. This is my main polemical purpose: starting with the narrow terms of the antidiscrimination principle, corrective ideas can insist upon a great deal. Before concluding, however, it is necessary to say something more about some characteristic problems involved in working with corrective principles, particularly in the desegregation context.

The problems most relevant here result from the fact that the prohibitions and requirements of the corrective conception are context-bound and time-bound. ${ }^{181}$ The unique moral force of the corrective conception, after all, rests upon the existence of a link between

$22,1986)$. Even though it might seem that few suburban districts will volunteer to participate in such an arrangement (unless they feel clearly threatened with a finding of interdistrict violations and a court order requiring much more drastic metropolitan busing), this is not necessarily correct. In the Liddell situation, the state had already been found in violation and therefore was required to fund any interdistrict transfer plan. In such cases, suburban communities have a positive incentive to voluntarily join in solving what is, after all, a serious regional problem of racial isolation.

180. The Liddell court stated that interdistrict transfers further the corrective goal of eliminating effects of an intradistrict violation, $731 \mathrm{~F}, 2 \mathrm{~d}$ at 1306-08; it reaffirmed that even though a city and state's constitutional violation is intradistrict, not interdistrict, an equitable remedy may extend beyond the district boundaries when it does not infringe on the suburbs' local autonomy, id. at 1306-09; it reaffirmed that if the state is guilty of sharing in the violation the state can be required to pay the costs of the remedy, id. at 1297, 1311; and it explicitly recognized that an interdistrict transfer plan funded by the state does not "restructure" or "reorganize" the suburban districts, id. at 1308 (citing Milliken I and Gautreaux).

181. There are other characteristic problems that arise in working with the corrective conception that I do not specifically address here-for example, determining the most appropriate cost-bearers and most appropriate beneficiaries of remedial action. Sce also supra note 77; infra note 194 (problem of color-consciousness during the transition period). 
present conditions (which are the focus of a remedy) and prior wrongful acts of purposeful discrimination. It is the struggle to be free of an impinging, wrongful past that unleashes remedial liberties and gives the corrective enterprise its stature. But this means that the moral power of the corrective conception rests upon an empirical claim that must be established in each case. Corrective steps are justified only to the extent that prior wrongs have current effects. Before initiating a remedy, therefore, courts must sort out which, if any, present conditions are traceable to past discrimination and, once the remedy is implemented, must determine when the remedy has actually eliminated those effects so that judicial intervention may terminate. Thus, while a court acts improperly if it fails to invoke corrective rules where appropriate, it also acts improperly if it imposes those rules beyond the boundaries of their remedial justification. Corrective steps are transitional rules only. Because the transitional rules are bounded, a court must address boundary issues through time, determining occasions for initiating and then terminating the temporary remedial period.

\section{A. Context: General Empirical Problems}

Boundary issues arise whether the corrective frame is narrow or broad, but in a desegregation suit, where remedies are furnished only for proven violations of the Constitution, the court must stay within a narrow corrective frame. A court may seek to eliminate only those segregated conditions that are found to result from the defendant's purposeful discrimination. No remedy is appropriate, for example, if the racial character of the schools results only from the cumulative effects of others' past discrimination or from individual residential choices that are themselves untainted by the defendant's discrimination. Similarly, to set aside a choice system that was not tainted by the effects of the defendant's past violations would exceed a court's remedial authority.

To stay within the boundaries of its remedial authority, therefore, the court must become involved in complex questions of causation. Determining that some condition has been "caused" by the defendant's discrimination depends not only on the facts of a particular case, but also on the legal standard of causation to be applied to those facts. The courts, however, simply have not used any consistent standard of causation-in-fact in discrimination cases; they seem instead to vacillate between the position that the defendant's discrimination must be a "but for" cause and the position that it need only be a "contributing" cause of the condition to be remedied. ${ }^{182}$ Beyond these conceptual and legal

182. The ambiguity in the cases is captured well on a single page of one case: [T] he prima facie case may . . . be met by evidence supporting a finding that a lesser degree of segregated schooling . . . would not have resulted even if the Board had not acted as it did. . . . [The defendant] can rebut the prima facie case only by showing that its past segregative acts did not create or contribute to the current segregated condition of the ... schools. 
ambiguities, of course, are the ambiguities of reality. The courts will usually be assessing the cumulative effects of the discriminatory actions of individuals and institutions over a considerable period of time. The path of consequences will usually be complex and will include many interactive effects. Moreover, the court must sort out those conditions caused by factors unrelated to discrimination.

The problem raised by these empirical uncertainties is not only that a court may start searching for the unknowable or may make mistakes. In addition, in trying to resolve empirical uncertainties, the courts may draw upon distributive norms that go beyond the corrective idea itself. In the name of evaluating whether a pupil assigument system is infected by discrimination, a judge may be led to measure the system simply by the extent to which it produces a preferred end-state distribution. For example, a judge attempting to decide whether the choice to attend a racially separate school is tainted may ask what a "reasonable" person would have chosen in an untainted situation and in doing so may end up drawing upon his own substantive values concerning the desirability of integration in the end-state. But such an im-

Keyes v. School Dist. No. 1, 413 U.S. 189, 211 (1973) (emphasis added); see also id. at 214 (defendant responsible for current systemwide segregation if its prior intentional segregative acts were simply "factors in causing the existing condition of segregation") (emphasis added). For other examples, compare Columbus Bd. of Educ. v. Penick, 443 U.S. 449, 465 n.13 (1979) ("contributing cause"); Dayton Bd. of Educ. v. Brinkman (Dayton II), 443 U.S. 526, 537 (1979) (defendant responsible for current segregated conditions if they were "caused at least in part by [the defendant's] prior intentionally segregative official acts") (emphasis added); and id. at 541 (systemwide remedy appropriate if "a sufficient case of current, systemwide effect had been established") (emphasis added) with Givhan v. Western Line Consol. School Dist., 439 U.S. 410, 417 (1979) ("but for"); Mt. Healthy City Bd. of Educ. v. Doyle, 429 U.S. 274, 287 (1977) (same); Arlington Heights v. Metropolitan Housing Dev. Corp., 429 U.S. 252, 271 n.21 (1977) (same); and Dayton Bd. of Educ. v. Brinkman (Dayton I), 433 U.S. 406, 420 (1977) ("must determine how much incremental segregative effect these violations had on the racial distribution . . . as presently constituted, when that distribution is compared to what it would have been in the absence of such constitutional violations"). Not surprisingly, the most sophisticated judicial discussion of causation in antidiscrimination law is by Judge Robert Keeton, in LeBoeuf v. Ramsey, 503 F. Supp. 747 (D. Mass. 1980).

An unusual approach to the causation issue has recently appeared in tort law and might well have useful application in the antidiscrimination field. In Sindell v. Abbott Laboratories, 26 Cal. 3d 588, 607 P.2d 924, 163 Cal. Rptr. 132, cert. denied, 449 U.S. 912 (1980), the Supreme Court of California held that when a plaintiff cannot identify the precise manufacturer of the drug that barmed her, each manufacturer should be liable for its proportionate "market share" of plaintiff's damage. See W. Keeton, D. Dobbs, R. Keeton \& D. Owen, Prosser and Keeton on the Law of Torts, $\S \S 41,103$, at 271-72, 712-15 (5th ed. 1984). Sindell responds to the problem of sorting out responsibility among multiple wrongdoers each of whom undoubtedly committed wrongs in the past, but none of whom can be specifically tied to a particular victim. This precise problem has frequently burdened victims in racial discrimination cases, and some version of the Sindell approach may be appropriate here as well. As a general matter, the politically charged fields of antidiscrimination law and scholarship reveal a curious innocence about tort law concepts that might enrich analysis and be useful to litigants and scholars on all sides of the issues. 
position of an externally preferred end-state distribution is precisely what the corrective conception claims to avoid.

These difficulties are probably best illustrated by the most common problem in school desegregation cases-deciding whether a confusing set of facts establishes that a systemwide segregated pattern was caused by the defendant's segregative acts and is therefore subject to a systemwide remedial desegregation decree. We know that longstanding intentionally segregative practices not only are the direct cause of pupil segregation, but can unleash a segregative dynamic that over time increases the degree of segregation and makes it self-perpetuating; as the courts have repeatedly noted, the defendant's discrimination may determine the location and capacity of permanent school sites, affect residential patterns, and have a range of other interactive consequences that exacerbate pupil segregation. ${ }^{183}$ Other demographic forces, however, operate independently of the defendant's discrimination. Thus, it is often extremely difficult to sort out the causal story and determine the precise extent to which currently observable segregated patterns are traceable to the defendant's discrimination.

The Supreme Court's method of dealing with this empirical uncertainty about the violation's scope has been controversial. The Court has held that once the plaintiff makes a specific threshold showing that the defendant purposefully segregated in at least a substantial part of the school system, it will be presumed (rebuttably) that present segregated patterns throughout the school system were caused by the defendant's discrimination. ${ }^{184}$ This rebuttable presumption-commonly called the "Keyes presumption"-has facilitated findings of extensive segregative effects and therefore has provided a predicate for extensive desegregation remedies. Critics have questioned the use of this rebut-

183. Schools may be located and sized in a way that takes advantage of residential segregation that already exists, facilitating the achievement of pupil segregation. An extreme example is when a school is placed in a predominantly white neighborhood at the end that is farthest from a black neighborhood. When segregative siting of new schools is joined with the deliberately segregative closing of other schools, the segregative consequences can be difficult to reverse even if pupil assignment policies themselves become racially neutral. See Keyes v. School Dist. No. 1, 413 U.S. 189, 201-03 (1973).

A policy of school segregation also has probably promoted residential segregation, either because people have tended to move closer to their (segregated) schools, id., or because school segregation has "taught lessons of racial prejudice and hostility which molded and reinforced prejudicial attitudes [that] influenced . . . housing decisions," Armstrong v. O'Connell, 463 F. Supp. 1295, 1309 (E.D. Wis. 1979), or because a long regime of school segregation contributed to a cycle of black economic and social disadvantaging that in turn has contributed to residential segregation. See United States v. Texas Educ. Agency, 600 F.2d 518, 525 (5th Cir. 1979). This is another reason that past school segregation will have continuing effects on school attendance patterns long after deliberate school segregation has stopped.

184. Keyes v. School Dist. No. 1, 413 U.S. 189, 201 (1973); see Dayton Bd. of Educ. v. Brinkman (Dayton II) 443 U.S. 526, 537 (1979); Columbus Bd. of Educ. v. Penick, 443 U.S. 449, 467-68 (1979); accord Fiss, supra note 25, at 21-26. 
table presumption, arguing that it improperly simplifies the empirical problems facing plaintiffs and leads to remedies that exceed the plausible scope of the violations and the proper boundary of the corrective enterprise. ${ }^{185}$

The Keyes presumption, however, seems to me an altogether appropriate way of applying the corrective conception and dealing with the empirical problems it raises. Presumptions (like other rules for allocating burdens of proof) tell a court which way to decide a case in situations of empirical uncertainty. Traditionally, there are two basic justifications for shifting the burden of persuasion by means of a rebuttable presumption: (1) The presumption will contribute to determination of the truth; and/or (2) the presumption will lead to a preferred allocation of error costs. ${ }^{186}$ The rebuttable presumption in school segregation cases may be defensible even on the first ground. Once the plaintiff has satisfied his threshold burden, antecedent probabilities about the scope of segregative purposes and effects suggest that the truth is more likely to lie in the direction of the presumption (that is, that the defendant is responsible for the segregated attendance patterns and racial identification of schools throughout the system). ${ }^{187}$ In addition, the defendant is likely to have more accurate information about causes and demographic consequences and, therefore, should be given incentives to reveal it.

Even more clearly, the Keyes presumption is defensible as reflecting a value judgment: given that any system of proof will lead to wrong factual conclusions in some cases, it is preferable for errors of factfinding to be made in plaintiff's favor once the plaintiff has shown that the defendant purposefully segregated in at least a substantial part of the

185. See Fiss, supra note 25, at 22-26; Goodman, Some Reflections on the Supreme Court and School Desegregation, in Yarmolinsky Collection, supra note 149, at 45, 51-68; Kurland, supra note 87, at 362; Hearings Before the Subcomm. on Separation of Powers of the Comm. on the Judiciary, U.S. Senate, 97th Cong., 1st Sess. 592 (1981) (statement of William Bradford Reynolds, Jr.).

186. On allocating presumptions and burdens of proof more generally, see $9 \mathrm{~J}$. Wigmore, Evidence $\S \S 2485-2489$ (3d ed. 1940); McCormick on Evidence $\S \S 337,343$ (E. Cleary 3d ed. 1984).

187. This conclusion rests primarily on the likelihood that a defendant shown to have intentionally segregated in one area of the school system has in fact (1) deliberately made choices with a segregative rather than integrative purpose throughout the school system; and (2) caused continuing segregative effects throughout the system because of the "segregative dynamic" noted supra note 183 and accompanying text. See Keyes v. School Dist. No. 1, 413 U.S. 189, 201-14 (1973); Gewirtz, supra note 15, at 640-41, 646-67. Systemwide effects are particularly clear with respect to the racial identity of the schools: once the school board is found to have branded a substantial number of schools with a racial identity, it is both reasonable and likely that people in the community will conclude that the government is responsible for the observable racial character of other schools in the system, cf. Keyes, 413 U.S. at 196 (definition of segregated school includes "the community . . . attitudes toward the school"), especially if the legal standard holds the defendant to account if it is only a "contributing" cause of that racial identity. 
school system. ${ }^{188}$ The Keyes presumption is not triggered until the defendant is already shown to be a substantial wrongdoer. At that point, to put the burden on the defendant to demonstrate that some segregated conditions in the city are not the product of its own purposeful segregation (but in fact result from other causes) seems like an altogether fair allocation as between a proven violator and an innocent (indeed victimized) plaintiff class. Indeed, the difficulties of tracing out the causal links over time are themselves usually a product of the fact that the defendant's violation and failure to take corrective steps have lasted for so long a period. The burden of empirical uncertainties generated by the defendant's own unlawful conduct should not fall on the plaintiff. The Supreme Court has repeatedly invoked this rationale to ease plaintiffs' burden of proof in antitrust cases, ${ }^{189}$ and it should be at least as applicable in antidiscrimination cases.

Another possible basis for the presumption might be more troublesome, however. The presumption might be based on a view that any errors should be made in the direction of findings that would support a broader integration remedy because integration is considered to be a preferable condition to separation, without regard to whether it fits as a remedy for the defendant's violation. Professor Fiss, for example, seems to think this is the only plausible rationale for the presumption and argues that this shows that the Court is really committed to a distributive approach rather than what I have called a corrective approach. ${ }^{190}$ If the presumption in fact were based on a distributive rationale, it would reflect a preference among outcomes that goes beyond the narrow version of the corrective conception. Such a preference for integration might be rooted in a commitment to a broad version of the corrective idea (a commitment to eliminate effects of pervasive society-wide discrimination) or rooted in a distributive theory of integration completely independent of corrective notions. But in either case, using the presumption would broaden the corrective frame, incorporating a more expansive egalitarian norm into a theory that ostensibly is only narrowly corrective.

188. See Kejes, 413 U.S. at 209.

189. See, e.g., J. Truett Payne Co. v. Chrysler Motors Corp., 451 U.S. 557, 565-68 (1981), where the "traditional rule excusing antitrust plaintiffs from an unduly rigorous standard of proving antitrust injury" is described. 1d. at 565. The rule rests in part on the fact that "vagaries of the marketplace usually deny us sure knowledge of what plaintiff's situation would have been in the absence of the defendant's antitrust violation," id. at 566, and also reflects the sentiment that "it does not 'come with very good grace' for the wrongdoer to insist upon specific and certain proof of the injury which it has itself inflicted," id. at 566-67 (quoting United States Trust Co. v. O'Brien, 143 N.Y. 284, 289, 38 N.E. 266, 267 (1894)); see Zenith Radio Corp. v. Hazeltine Research, Inc., 395 U.S. 100, 123-24 (1969) (same); Bigelow v. RKO Radio Pictures, Inc., 327 U.S. 251, 264-65 (1946) ("Any other rule would enable the wrongdoer to profit by his wrongdoing at the expense of his victim .... [T]he more grievous the wrong done, the less likelihood there would be of a recovery.").

190. Fiss, supra note 25, at 26. 
As I hope I have demonstrated, however, the Keyes presumption need not, and does not, rest on this last rationale, since other traditional justifications for presumptions support it. Even if it did, however, use of the presumption would not destroy the basic integrity of the narrow remedial approach and collapse it into some broader theory. There is a difference between using a distributive norm as a fair or administratively convenient proof rule and using that distributive norm as the ultimate basis for allocations. In the former situation, a court remains bound by the narrow corrective frame. Indeed, the presumption here is explicitly rebuttable; in situations where a defendant can establish that segregated conditions result from causes independent of its own discrimination, the defendant prevails. ${ }^{191}$ The work done by the distributive norm when used as part of a proof rule is therefore shortlived. Moreover, the moral impetus for any transformative action remains rooted in corrective norms.

The corrective conception undoubtedly requires us to address issues of empirical complexity, and here, as in other areas of the law, we will probably have to settle for approximations and some measure of imprecise factfinding. ${ }^{192}$ The imprecision here results from the nature of the beast which we are rightly hunting down. Discrimination and its effects are often embedded in a community's life in complex and interactive ways. In most cases we will not doubt that the defendant's longstanding discrimination has had significant current effects; the empirical problems are ones of assessing the precise scope of those effects. What is our alternative to making that effort? We could, I suppose, ignore the beast because we fear that we will make mistakes in ferreting it out. But to ignore past discrimination would mean perpetuating and exacerbating its terrible effects. From the perspective of providing corrective justice, this means many "mistakes" of a different sort. Why should the goal of avoiding some mistaken determinations outweigh the goal of avoiding a mistaken undercorrection of discrimination? To limit or reject the corrective conception because of empirical problems in precisely tracing out causal links is to turn the very

191. Critics of the presumptions at times take a position that seems self-contradictory. On the one hand, they suggest that conclusions reached by the presumptions are plainly improbable; on the other hand, they consider the presumptions virtually impossible to rebut. See Fiss, supra note 25, at 19, 21; Goodman, supra note 185, at 52-55; Kurland, supra note 87 , at 362 . If the causal links are so unknowable, however, how can the critics be so sure that the presumed causal connections are so improbable? If the presumptions are so obviously improbable, then trial judges will be quite willing to make the necessary inferences to support defendant's rebuttal. Justice Stewart, in his separate opinion in Columbus Bd. of Educ. v. Penick, 443 U.S. 449, 478-79 (1979), predicted that trial courts will be quite able to make the necessary inferences. As argued in the text, moreover, to the extent that there is genuine uncertainty about the causal connections, it seems fair to place the burden on the defendant once it has been shown to be a substantial violator.

192. See supra note 60 and note 189 and accompanying text. 
extensiveness and duration of wrongs into an excuse for doing nothing about them.

At the other extreme, of course, we might look for a distributive approach to replace the corrective conception and its empirical complexities. The corrective approach, after all, is hardly the only possible theory of social justice, and it certainly is not the theory that can generate the greatest amount of redistribution. To abandon the corrective idea, however, is to abandon the unique moral claim of black Americans, a claim rooted in the undeniable fact of past discrimination and the special status of such wrongs. Moreover, it would simply introduce complexity of a different and probably more difficult sort-the complexity of defending a more extreme normative view.

\section{B. Time: The Problem of Termination}

Policing the boundaries of the corrective conception also has a temporal dimension-the problem of termination. Corrective intervention is supposed to be temporary, merely transitional; it is supposed to eliminate effects of the violation and then terminate. This, in fact, is one of the things that most clearly distinguishes the corrective and distributive approaches: under a corrective approach, intervention ends once the effects of discrimination end, while a distributive approach anticipates ongoing intervention to maintain the preferred distribution. Moreover, the assumption that corrective steps will be bounded in duration is at the core of what justifies the liberties of the corrective period, such as the courts' displacement of the usual institutions of policy making and administration in a locality, and the transitional use of remedial rules that conflict with end-state rules. But when does the transition end, and how will we know that point when we see it?

The termination issue arises in any version of the corrective conception, narrow or broad. In the desegregation context, it means that at some point after initiating a remedy, a court must self-consciously stop thinking about integration and choice in one way and start thinking about them in another way. It must stop supervising a decree requiring integration and start allowing the school board greater flexibility, including the use of any type of choice system the defendant wishes (provided doing so does not constitute a new unconstitutional act of intentional discrimination). ${ }^{193}$ The question of termination is also highly relevant, of course, to the issue of affirmative action. Proponents of affirmative action, of which I am one, defend race-conscious preferences as a necessary remedial step that is only temporary, that will not require the permanent abandonment of the public norm of colorblindness. ${ }^{194}$ But when does the temporary period end?

193. For another way of understanding the meaning and the consequences of a declaration of unitariness, see infra note 209 .

194. The liberty to be race-conscious during the transition period is now quite well 
The issues involved in terminating a remedy generally mirror those a court faces when initiating a remedy. But the termination question sharpens the focus. At the point of initiation, it may be unnecessary to define remedial goals precisely or choose among rationales of differing breadth. When the question of termination is raised, however, ambiguities about precise goals and rationales have to be resolved. Empirical issues will have to be faced in more detail. Moreover, termination may pose a political problem. Since the remedial regime is likely to last for a while, it may produce expectations and vested interests; these entrenchments may make termination a more bitterly contested issue than the initial question about whether to undertake a remedy at all. In fact, the likely political conflict around the termination issue creates the danger that the temporary rule will become permanent. Indeed, that danger may arise out of a subtler dynamic: the experience of the transition may change our attitudes by making us accustomed to what had initially seemed barely tolerable even temporarily.

The termination issue is a neglected one in writings about antidiscrimination law, but addressing it is one of the obligations of those who endorse corrective policies. Addressing it now also has become a practical necessity. The Reagan Administration has recently begun an effort to force the termination issue in the desegregation area, and over the next few years the issue is likely to become one of the most important in the civil rights field. The Administration has raised the issue in two ways: It has tried to persuade courts to declare that school systems currently under court order are now "unitary" and therefore should no longer be subject to a judicial remedial decree, ${ }^{195}$ and it has itself en-

established in the law, both in the areas of school desegregation and employment. See Fullilove v. Klutznick, 448 U.S. 448 (1980); United Steelworkers v. Weber, 443 U.S. 193 (1979); Swann v. Charlotte-Mecklenburg Bd. of Educ., 402 U.S. 1, 19 (1971); North Carolina State Bd. of Educ. v. Swann, 402 U.S. 43, 46 (1971). But cf. Wygant v. Jackson Bd. of Educ., 54 U.S.L.W. 4479 (U.S. May 1986) (indicating limitations); Firefighters v. Stotts, 467 U.S. 561 (1984) (same); Regents of the Univ. of Calif. v. Bakke, 438 U.S. 265 (1978) (same). This policy should be viewed as similar to the other liberties of the transition wbich allow courts to use remedial rules that are different from end-state rules in order to eliminate effects of past discrimination. There is one difference, of course: color-consciousness would be unconstitutional in the end-state. While that hardly establishes its inappropriateness during the remedy period, it clearly heightens wbat is at stake if the transition period is not terminated at the proper time.

195. See, e.g., Brief for the United States as Amicus Curiae at 11-37, Riddick v. School Bd., 784 F.2d 521 (4th Cir. 1986); Post-Trial Memorandum of the United States as Amicus Curiae on Defendants' Motions of Jan. 19, 1984, Keyes v. School Dist. No. 1, No. C-1499 (D. Colo. Aug. 16, 1984). The district court in Keyes rejected the Department's position in its ruling of June 3, 1985, 609 F. Supp. 1491 (D. Colo.). Cf. Supplemental Brief of the United States, Davis v. Board of School Comm'rs, No. 3003-63-H (S.D. Ala. Sept. 23, 1985) (arguing that this system has not achieved unitary status, but applying the standards set forth in the earlier briefs). The Department has now apparently begun a more general effort "to rekindle interest in getting [existing desegregation] orders modified or lifted" throughout the country. See Effron, Mandatory Busing Made Quiet Target at Justice Dep't, L.A. Daily Journal, Apr. 16, 1985, at 1, col. 6. 
tered into settlements with school boards which provide that after three years of "good faith" implementation of a choice plan the school system will be declared "unitary." 196

The Supreme Court has said relatively little about the termination issue in desegregation cases. In Swann v. Charlotte-Mecklenburg Board of Education, ${ }^{197}$ the Court observed in general terms that:

At some point, these school authorities and others like them should have achieved full compliance with this Court's decision in Brown I. The systems would then be "unitary" in the sense required by our decisions in Green and Alexander. . . . Neither school authorities nor district courts are constitutionally required to make year-by-year adjustments of the racial composition of student bodies once the affirmative duty to desegregate has been accomplished and racial discrimination through official action is eliminated from the system. ${ }^{198}$

Five years later, Pasadena City Board of Education v. Spangler ${ }^{199}$ lent some force to these observations. There the Supreme Court ordered modification of a lower court decree because it violated Swann's admonition that a judge has no further power to require annual readjustment of attendance zones " "once the affirmative duty to desegregate has been accomplished." " But the Court was not precise about what conditions would define the "accomplishment" of the affirmative duty. The holding in Spangler was a narrow one because the Court understood the trial judge to have asserted the power to maintain a particular racial balance in the schools "in perpetuity," 200 without regard to whether the affirmative duty to desegregate had already been "accomplished" and a "unitary system" already achieved. ${ }^{201}$ This was obviously inappropriate. ${ }^{202}$

196. Over the last three years, consent decrees containing this "good faith" provision have been entered into with school districts in Bakersfield, California; Marion County, Florida; Lubbock, Texas; Lima, Ohio; Phoenix, Arizona; and Hattiesburg, Mississippi. These consent decrees are all unpublished and are on file at the offices of the Columbia Law Review.

197. 402 U.S. 1 (1971).

198. 1d. at 31-32. Monroe v. Board of Comm'rs, 391 U.S. 450 (1968), noted earlier, see supra notes 68-69 and accompanying text, can also be read as a case about terminating a remedial prohibition on freedom of choice. There, even though the defendant first reassigned all pupils to geographically-zoned schools instead of making racial assignments, that change was deemed insufficient to allow the defendant to add a transfer option.

199. 427 U.S. 424 (1976).

200. 1d. at 436 . The trial judge had stated that his remedial decree meant that "there would be no majority of any minority [group]" in any Pasadena school "at least during my lifetime," and that he would require annual readjustments to maintain that racial balance. Id. at 433-35.

201. Thus, as the Court understood it, the trial judge had claimed a power to readjust pupil attendance patterns which were not "in any manner caused by segregative actions chargeable to the defendants" or "caused by so-called 'white flight' traceable to the decree itself." 1d. at 435. The Court also noted that it did not understand the district court's decree to be a " 'step at a time' plan[] by definition incomplete at incep- 
The central termination question, though, is what it means to "accomplish" desegregation and achieve "unitary" status. In a general sense, that moment is reached when the defendant shows that continuing effects of its past discrimination have been eliminated and the prospects of future discrimination have dissipated. ${ }^{203}$ But the Court has not given practical guidance on how to identify that moment. Nevertheless, one can safely say that desegregation is not "accomplished" as soon as a desegregation plan is adopted. ${ }^{204}$ A "plan" is just that: a proposal

tion." Id. However, the Court did hold that accomplishing one component of a multicomponent decree could release the defendant from that component. Id. at 436-37.

202. The Supreme Court has also referred to the termination question in several contexts other than school desegregation. See Fullilove v. Klutznick, 448 U.S. 448,513 (I980) (Powell, J., concurring) (noting that the minority set-aside legislation "is not a permanent part of federal contracting requirements," but contained an explicit termination provision); United Steelworkers v. Weber, 443 U.S. 193, 208-09 (1979) (noting that one feature establishing the permissibility of the affirmative action plan was that it was "a temporary measure" and would "end as soon as the percentage of black craftworkers [in the plant] approximates the percentage of blacks in the local labor force"); cf. Califano v. Webster, 430 U.S. 313, 320 (1977) (noting that the challenged preferential policy for certain female social security recipients had already ended).

A number of lower courts have considered the issue of when particular school desegregation decrees should terminate. The more significant decisions include: Vaughns v. Board of Educ., 758 F.2d 983 (4th Cir. 1985) (rejecting termination); Tasby v. Wright, 713 F.2d 90 (5th Cir. 1983) (rejecting termination); Ross v. Houston Indep. School Dist., 699 F.2d 218 (5th Cir. 1983) (allowing termination); United States v. Texas Educ. Agency, 647 F.2d 504 (5th Cir. 1981) (rejecting termination), cert. denied, 454 U.S. 1143 (1982); Morgan v. O'Bryant, 687 F.2d 510, 517 (1st Cir. 1982) (discussing standards); Adams v. United States, 620 F.2d 1277, 1296 n.31 (8th Cir.) (requiring retention of jurisdiction to insure effectiveness of desegregation plan), cert. denied, 449 U.S. 826 (1980); Spangler v. Pasadena City Bd. of Educ., 611 F.2d 1239 (9th Cir. 1979) (allowing termination); United States v. Texas, 509 F.2d 192 (5th Cir. 1975) (vacating order of termination for lack of adequate procedure); Steele v. Board of Pub. Instruction, 448 F.2d 767 (5th Cir. 1971) (determining that district court should retain jurisdiction for a few years even after declaration of unitariness); Youngblood v. Board of Pub. Instruction, 448 F.2d 770 (5th Cir. 1971) (establishing notice and hearing procedures required prior to termination); Keyes v. School District No. 1, 609 F. Supp. 1491 (D. Colo. 1985) (rejecting termination); Morgan v. Nucci, C.A. No. 72-911-G (D. Mass. Sept. 3, 1985) (allowing termination). Despite the Administration's particular attention to the case involving Norfolk, Virginia, see, e.g., Wash. Post, Feb. 8, 1986, at A11, col. 1, the Fourth Circuit's recent decision allowing termination sheds little light on the fundamental issues. Riddick v. School Bd., 784 F.2d 521 (4th Cir. 1986). The case involved an unusual situation where plaintiffs had consented years earlier to an order declaring the school district "unitary." For that reason, the case seems much less significant than many of the other lower court decisions addressing the termination issue.

203. See Green v. County School Bd., 391 U.S. 430,439 (1968). The burden of establishing this is clearly on the defendant. See Ross v. Houston Indep. School Dist., 699 F.2d 218, 225 (5th Cir. 1983). Green also noted six major areas which would be examined before determining that a school system was unitary: "[S]tudent bodies[,] . . . faculty, staff, transportation, extracurricular activities and facilities." 391 U.S. at 435.

204. See, e.g., Raney v. Board of Educ., 391 U.S. 443, 449 (1968); Ross v. Houston Indep. School Dist., 699 F.2d 218, 225 (5th Cir. 1983). 
that anticipates success but neither guarantees success nor brings it about immediately. Thus, "accomplishment" of desegregation requires that a plan be fully implemented and kept in place for a period of time.

The effects of a violation are not erased the moment integration is achieved. One goal of a desegregation remedy, for example, ${ }^{205}$ is to eliminate the racial identifiability of schools. That goal, if taken seriously, cannot be achieved by producing an integrated student body in the schools for a day, or even for a year. A period of sustained compliance, perhaps an entire generation, is needed for public perceptions about the racial character of the schools to be transformed.206 Or to take another example: as the courts have repeatedly recognized, longstanding de jure segregation has affected school site locations and residential patterns. ${ }^{207}$ Desegregation, presumably, is not accomplished until these effects of the violation are reversed or no longer have any segregative effect on schools in the district. ${ }^{208}$ But this cannot happen overnight. The remedy must be in place for a siguificant period of time-until, for example, school locations and residential patterns have evolved so that a school board decision to return to a neighborhood assignment system, or to eliminate the magnet schools from a choice system, would not perpetuate effects of prior segregative actions. ${ }^{209}$

205. Somewhat different issues are raised by the question of when Milliken II compensatory education remedies should terminate.

206. See Keyes v. School Dist. No. 1, 413 U.S. 189, 196 (1973) (definition of segregated school includes "the community . . . attitudes toward the school"); Vaughns v. Board of Educ., 758 F.2d 983, 991 (4th Cir. 1985) (rejecting termination because certain schools' "identities as black schools had never been eradicated"). As one desegregation opinion put it, "[o]ne swallow does not make a spring." Lemon v. Bossier Parish School Bd., 444 F.2d 1400, 1401 (5th Cir. 1971); see also Spangler v. Pasadena City Bd. of Educ., 611 F.2d 1239, 1241 (9th Cir. 1979) (as amended on denial of rehearing) (concluding that eight years is sufficient); Steele v. Board of Pub. Instruction, 448 F.2d 767, 767-68 (5th Cir. 1971) (three years may be enough); Singleton v. Jackson Mun. Separate School Dist., 541 F. Supp. 904, 914-15 (S.D. Miss. 1981) (10 years); United States v. Corinth Mun. Separate School Dist., 414 F. Supp. 1336, 1339-40, 1345 (N.D. Miss. 1976) (five years).

207. See supra note 183 .

208. See Tasby v. Wright, 713 F.2d 90, 95 (5th Cir. 1983); Ross v. Houston Indep. School Dist., 699 F.2d 218, 226-27 (5th Cir. 1983).

209. See Columbus Bd. of Educ. v. Penick, 443 U.S. 449, 460 (1979) (court must ensure that school board's future actions "are not used and do not serve to perpetuate or re-establish the dual school system"); accord Dayton Bd. of Educ. v. Brinkman (Dayton II), 443 U.S. 526, 538 (1979).

Under the analysis in the text, the question of what a school board is entitled to do after the school system is declared unitary and remedies terminate is intertwined with the meaning of unitariness itself. After a declaration of unitariness, since all vestiges of the violation have by definition been eradicated, the school board may adopt a neighborhood assignment system or choice system even if it produces more segregation than under the court's remedial plan, provided that the board's action is not intentionally discriminatory and therefore is not a new constitutional violation. (Discriminatory intent might well be provable in a particular case, of course, but given the centrality of 
Another reason time is necessary, of course, is that the trial court may be mistaken in its initial judgment that its plan will "work."210 The court may discover that some step it hoped would succeed has in fact failed. Or revisions in the plan may be needed to take account of "white flight" and other demographic shifts that were caused by the decree or that otherwise interfere with the decree's effectiveness in dispelling the racial identity of the schools. ${ }^{211}$ While it would be error for

neighborhood assignment in American education, a return to such a system could not automatically be deemed intentional discrimination.) See Crawford v. Board of Educ., 458 U.S. 527, 543-45 (1982); Spangler v. Pasadena City Bd. of Educ., 611 F.2d 1239, 1245 (9th Cir. 1979) (Kennedy, J., concurring). Thus, the defendant would be free of substantive remedial constraints, although a court might retain jurisdiction for a modest period after declaring unitariness as a prophylactic measure to assure that new discrimination does not occur. See Ross v. Houston Indep. School Dist., 699 F.2d 2 18, 227, 230 (5th Cir. I983); Steele v. Board of Pub. Instruction, 448 F.2d 767, 767 (5th Cir. 1971) (per curiam). Because of these consequences of declaring "unitariness," a court must be careful not to make the declaration before all vestiges of the violation are actually eliminated.

An alternative approach has been suggested by a Justice Department official "off the record." The court might declare the school system unitary and terminate its remedial decree at an earlier point, but the school board would be required thereafter to maintain the basic elements of the remedial plan that produced the "unitary" system. It seems apparent, though, that there can only be two possible bases for constraining the school board's power to abandon the remedial plan at that point: Abandonment would amount to a new act of unconstitutional discrimination, or abandonment would perpetuate vestiges of the defendant's past violations. The former, as suggested above, is not necessarily true; and if the latter is true, I do not see how the system could really have been thought "unitary," or why the court should have "terminated" its substantive remedial decree rather than keep it in effect.

210. See, e.g., Green v. County School Bd., 391 U.S. 430, 439 (I968) ("whatever plan is adopted will require evaluation in practice, and the court should retain jurisdiction until it is clear that state-imposed segregation has been completely removed"); Vaughns v. Board of Educ., 758 F.2d 983, 989 (4th Cir. 1985) (modification of remedy needed); United States v. Texas Educ. Agency, 647 F.2d 504, 508 (5th Cir. 1981), cert. denied, 454 U.S. I 143 (I982); supra notes 130-33 and accompanying text (mandatory "back-up" cases).

211. White flight after a decree is implemented creates the need for further remedial steps for the simple reason that fight interferes with the remedy's effectiveness. See Gewirtz, supra note 15 , at $635-43,657$, and cases discussed therein. This is obviously so where the flight is itself encouraged by the defendant's segregation or by the decree that seeks to remedy the defendant's segregation. The fact that courts routinely choose remedial steps that try to minimize the extent of flight underscores the point. But even if flight is a demographic shift caused by factors other than the violation or remedy, it still can interfere with the remedy's effectiveness. Once the violation has created schools identified as "white" or "black," dispelling that racial identity requires that integration be maintained for a long enough period of time to change the public's perception of the schools-and demographic shifts that cause resegregation interfere with that transformation process. Some judges appear to ignore the remedial significance of demographic shifts, but these opinions are best read as standing for the proposition that once the schools' racial identity has already been dispelled, subsequent demographic shifts do not trigger any decree-revision power, even if a segregated pattern reestablishes itself. See, e.g., South Park Indep. School Dist. v. United States, 439 U.S. 1007, 1011 (1978) (Rehnquist, J., dissenting from denial of cert.) (district court "has no authority [] to 
the court rigidly to insist on the achievement of the precise integration percentages projected in the initial plan, ${ }^{212}$ or to compel readjustments of the racial balance once desegregation is "accomplished," 213 a court is right to insist that the remedy "work" to produce a result: the actual elimination of racially-identified schools. In revising (rather than terminating) a plan that falls short, the court does no more than carry out its duty to eliminate effects of the violation. In sum, we should not be surprised or lose patience if the corrective enterprise requires a long period of sustained judicial intervention, including some modifications, in order to be effective. Where discrimination persisted and spread its harms for decades or longer, it may take decades or longer to reverse the process.

Even this brief discussion indicates what is unacceptable about the Reagan Administration's position on termination. The Administration has argued that termination of a school desegregation remedy is appropriate once "the defendant school authorities have fully and faithfully implemented a constitutionally-acceptable desegregation plan designed . . . to eliminate all vestiges of the prior dual system . . . [and] have subsequently engaged in no intentionally segregative acts";214 its "blueprint" consent decree with school boards provides for termination three years after a plan is implemented. ${ }^{215}$ However, even a plan that is "desigued" to achieve a unitary system may fail to do so. Three years is unlikely to be a long enough period for the plan to work, and the plan itself may need to be revised. The plaintiff's remedial rights cannot be terminated simply because of the defendant's good faith in implementing a plan that necessarily is only the defendant's first attempt to cure its wrongs. ${ }^{216}$ The measure of success must be the

monitor the plan indefinitely to make sure that the initial Swann requirements are maintained year after year in spite of demographic changes which are in no way attributable to the school board") (emphasis added); Ross v. Houston Indep. School Dist., 699 F.2d 218, 225 (5th Cir. 1983) ("[w] wen state officials . . . have actually achieved a school system clean of every residue of past official discrimination, . . . post-desegregation demographic changes . . . do not bar judicial recognition that the school system is unitary") (emphasis added); cf. Pasadena City Bd. of Educ. v. Spangler, 427 U.S. 424, 435 (1976) (noting that " "white flight' traceable to the decree" is not involved in that case).

212. See, e.g., Swann v. Charlotte-Mecklenburg Bd. of Educ., 402 U.S. 1, 24-25 (1971).

213. See Pasadena City Bd. of Educ. v. Spangler, 427 U.S. 424, 435 (1976).

214. Post-trial Memorandum of the United States as Amicus Curiae at 2, Keyes v. School Dist. No. 1, 576 F. Supp. 1503 (D. Colo. 1984); see Tofani, Justice Department Eases Standards for Finding Schools Bias-Free, Wash. Post, Aug. 31, 1985, at A4; supra note 195 .

215. See supra notes $145-47,195-96$.

216. The Department of Justice currently takes the position that a desegregation plan's failure to achieve projected integration goals is relevant only insofar as it is "probative of post-judgment intentional segregative conduct or bad faith implementation of the desegregation plan by the school board." Supplemental Brief of the United States at 28, Davis v. Board of School Comm'rs, Civ. Action No. 3003-63-H (S.D. Ala. Sept. 23, 1985). But integration goals reflect an independent requirement that integrative results 
achievement of results, not simply good faith.

The termination issue will necessarily be afflicted with all the empirical uncertainties discussed earlier, particularly the problems of tracing out the causal linkages and knowing when conditions properly viewed as effects of the defendant's discrimination have been eliminated. These uncertainties again raise the possibility that value preferences beyond those contained within the corrective conception itself will actually control its application. A basic question is whether one can decide that the effects of past discrimination have been eliminated without having some preferred distributive arrangement in mind. There is another problem here as well. If judicial remedial efforts are really justified so long as any harmful effects of discrimination persist, there is the possibility that remedies might continue almost indefinitely because the taints of past discrimination may persist in some form almost indefinitely. Indeed, as a society we will probably never completely free ourselves from our racial history; the impinging past will always be with us, our world always bound to that world. ${ }^{217}$ While it should hardly surprise us that it may take a very long time to eliminate the effects of decades or centuries of discrimination, the difficulty is that this may mean a long period of living with "transitional" measures which are themselves problematic-such as judicial displacement of other institutions and race-conscious remedies. These "transitional" measures are justified by their temporariness, and if the "transition" lasts virtually

actually must be achieved. While a court may not treat any specific numerical balance as a rigid and inflexible requirement, see supra note 212 and accompanying text, a plan has failed if it fails actually to eliminate "white" schools and "black" schools, Green v. County School Bd., 391 U.S. 430, 442 (1968), and to achieve "the greatest possible degree of actual desegregation, taking into account the practicalities of the situation." Davis v. Board of School Comm'rs, 402 U.S. 33, 37 (1971).

If the initial plan fails to achieve these results, a revised, more "effective" plan must be ordered. Such a revision is hardly a " "relitigation of issues that have been resolved by the judgment.' " Post-Trial Memorandum of the United States as Amicus Curiae at 13, Keyes v. School Dist. No. 1, 576 F. Supp. 1503 (D. Colo. 1983) (quoting 11 C. Wright \& A. Miller, Federal Practice and Procedure $\$ 2863$, at 206 (2d ed. 1973)). The judgment mandates certain basic remedial goals which the plan must meet; the goals have not been "relitigated" when a new plan is ordered to replace a plan that failed to achieve those goals. Necessarily, no particular paper plan can be a final and complete remedy until it is determined whether it actually works in the real world. In this sense all desegregation plans are " 'step at a time' plans by definition incomplete at inception." Pasadena City Bd. of Educ. v. Spangler, 427 U.S. 424, 435 (1976). This understanding of judicial decrees and their revision has been abundantly clear since at least United States v. United Shoe Mach. Corp., 391 U.S. 244 (1968), a case involving an antitrust decree that was decided a week before Green.

217. We also know that there are effects of the past that we will never want to eliminate, because oppression has spawned beauty too. In short, the very goal of "eliminating the effects of past discrimination" may be an illusion if taken literally, since it suggests that we can take ourselves out of time. An analogous point is made in Freud's brooding but magisterial discussion of the termination of anotber "corrective" process. Freud, Analysis Terminable and Interminable, reprinted in 23 The Standard Edition of the Complete Psychological Works of Sigmund Freud 216 (J. Strachey ed. 1964). 
indefinitely, the distinction between "transitional" and "end-state" policies all but disappears.

At the very least, some simplifying proof rule or mechanism of approximation seems unavoidable given the empirical difficulties of knowing when to terminate. The particular proof mechanism used may well reflect not only the probabilities about whether desegregation really has been fully accomplished, but also a further value judgment about where the risk of mistakes should fall. Thus, if a court is particularly concerned that the transitional remedy period not go on too long, it might resolve factual uncertainties in a direction that facilitates termination. For example, we saw above how the courts have used a presumption in determining the scope of the violation. ${ }^{218}$ Some period of time after the remedy is ordered, the presumption might shift-instead of presuming that effects of past violations still persist, the court might start presuming that those effects have been eliminated unless the plaintiff carries the burden of showing otherwise. On the other hand, if a court believes that it should be particularly careful that long-time victims are not once again wrongly shortchanged, it would resolve empirical uncertainties in the other direction. Undoubtedly, the particular proof mechanism adopted can affect when termination occurs, but, as suggested earlier, I do not think that a proof rule's reliance on values beyond the corrective conception collapses the corrective approach into a distributive one. The effort remains one of trying to implement corrective goals, and does not at all seek to maintain a particular distribution.

Values unrelated to corrective goals might, of course, play a larger role when a court decides when to terminate a remedy. Although patient persistence seems only fair when the violation itself lasted for a long time, it is possible that a court might end the remedial struggle even though it recognizes that corrective goals have not yet been fully achieved. While this might reflect simply a court's judgment that it is unable to do anything more, it could also reflect the court's unwillingness to do any more because the court concludes that a longer transition would excessively interfere with other social interests-such as returning full decisional power to nonjudicial officials or installing a regime of colorblindness. To promote these interests, a court might simply choose an arbitrary stopping point for its efforts, thereby allowing values beyond the corrective ideal to directly override the goal of full corrective justice. ${ }^{219}$

The path to termination can be a complex one. It is even possible

218. See supra notes $184-91$ and accompanying text.

219. Since courts are reluctant to acknowledge that they are providing only imperfect remedies, it may be difficult to tell exactly what any particular termination decision really signifies. For a rare example of a termination decision that acknowledges the imperfections of what courts can do, see Ross v. Houston Indep. School Dist., 699 F.2d 218, 227-28 (5th Cir. 1983). 
that choice plans could come to play a significant role in the termination process. Cognizant of the various empirical uncertainties and competing social interests that pervade the termination issue, and ambivalent about whether a mandatory integration decree should terminate, a court might compromise by refusing to terminate remedial steps altogether but, as a halfway measure, allowing school districts to utilize some form of choice remedy instead of mandatory integration. Most courts, of course, have held to mandatory measures and continue to try to mold a resistant reality into the shape of our ideals. These courts are not ready to claim success, or begin a phased withdrawal, or give up the struggle just yet. By whatever path, though, at some point-perhaps in words that could connote either triumph or despair-the court will come to say: it is finished.

\section{CONCLUSION}

The various complexities of bringing the corrective enterprise to a close suggest that it may be as much a viewpoint as an analytic tool. The corrective conception does not tell us exactly what to do. Rather, it insists upon an imagery and locates a source of commitment. The images are rooted in the past-the awful, deliberate wrongs inflicted on black people for so long, the brutal sweep of continuity between past deeds and present life. From that image of wrong comes the commitment to correction, the distinctive dynamic of racial justice. The corrective idea insists that racial justice not be assimilated to other distributive objectives. It affirms that, because of the past, the claims of black Americans are unique and uniquely just. It affirms, at the very least, a way of thinking about racial justice.

In the end a significant part of my dissatisfaction with choice remedies itself concerns images and ways of thinking. The invocation of choice suggests that the legacy of racism is appropriately addressed by leaving the problems to the victims themselves to confront one by one. That latent meaning may be the deepest insufficiency of choice. We need not accept an idea of collective guilt for our racial past to recognize a collective responsibility for purging our country of the continuing effects of that past. It is an obligation that derives from something as simple as the acceptance of citizenship in a nation whose glories have so long and so often been intertwined with racism. We have a duty to act as a society, through institutions of government and through a shared recognition of the common bonds of citizenship. To say "the choice is yours" is to deny our own duties. It is to turn away, when we should be turning toward. It misunderstands what must be done to counteract the terrible effects of long exclusion: not simply choice, but inclusion-integration in its best meaning. 